\title{
Problems of the Pannonian Basin geodynamics
}

\author{
A. F. Grachev and V. A. Nikolaev \\ Schmidt United Institute of Physics of the Earth, Russian Academy of Sciences, Moscow
}

\begin{abstract}
Joint analysis of geological-geophysical data and petrogeochemical characteristics of neotectonic volcanism revealed a close relationship between the neotectonic pattern of the Pannonian basin and deep structure. As shown in this work, main features of the recent deep structure such as the thin crust, hotter lithosphere and lower $P$ wave velocities can be accounted for solely in terms of the model of a mantle floating-up diapir that stretches the lithosphere. Such a tectonic regime is known as synorogenic rifting. The synorogenic rifting model is largely based on the evidence of alkali-basaltic volcanism developing since the beginning of the Pannonian Age (11-10.5 Ma), after the subduction had stopped and the previously widespread calc-alkaline magmatism had localized within the Transcarpathian region. The chemistry of basalts in the Pannonian basin is characterized by concentrations of major, rare and rare-earth elements fully consistent with petrogeochemical features of continental rift basalts. Ultrabasic xenoliths in Pannonian basin basalts belonging to the spinel lherzolite facies also coincide in composition with mantle xenoliths usually present in volcanics of rift zones. The data of this work indicate that evolutionary models of the Pannonian basin based on a passive response of the lithosphere to external factors are invalid. The preliminary results of geodynamic zoning presented in the paper suggest that such processing of the geological-geophysical database is promising, because it enables the identification of individual lithospheric blocks having specific features within a given geostructural province (differing in the relationships between geological-geophysical parameters). This approach provides deeper insights into the nature of the seismic activity in the Pannonian basin that has not been clearly understood as yet.
\end{abstract}

\section{Introduction}

The Carpathian-Balkan region (CBR) is the eastern extension of the Alpine mountain system, divided in the Vienna basin into the mountain structures of Carpathians and Dinarides.

Carpathians form an arc convex to the East European platform, and the southern part of this arc along with the mountainous Balkanides is the natural boundary of the Moesian platform. Being the northeastern continuation of the East Alps, the Carpathian arc is divided into three segments:

Copyright 2002 by the Russian Journal of Earth Sciences.

Paper number TJE02105.

ISSN: $1681-1208$ (online)

The online version of this paper was published 26 September 2002. URL: http://rjes.wdcb.ru/v04/tje02105/tje02105.htm
Western, Eastern and Southern Carpathians characterized by specific lateral zonality. The following zones are recognizable in the direction from the platform to the Carpathian arc: the Carpathian foredeep and Outer and Inner Carpathians.

The Carpathian arc bounds the Pannonian basin (PB); along with its peripheral basins (Vienna, West Danubian (Trans-Danubian), Transcarpathian and Transylvanian), the latter is bounded by the Dinarides to the southwest (Figure 1).

The Balkan Mountains (Stara Planina), which join the platform via the narrow Balkan foredeep striking $\mathrm{E}-\mathrm{W}$, are south of the Mysian platform. A system of intermontane basins separates the Balkan Mountains from the KrainshtenMidmountains uplift area. The boundary of the latter with the Rhodope Massif coincides with the Maritsa fault. Structural elements south of the Rhodope Massif are bounded to the west by the Strimon tectonic line (pre-Eocene thrust), where they join the Serbian-Macedonian Massif and north- 


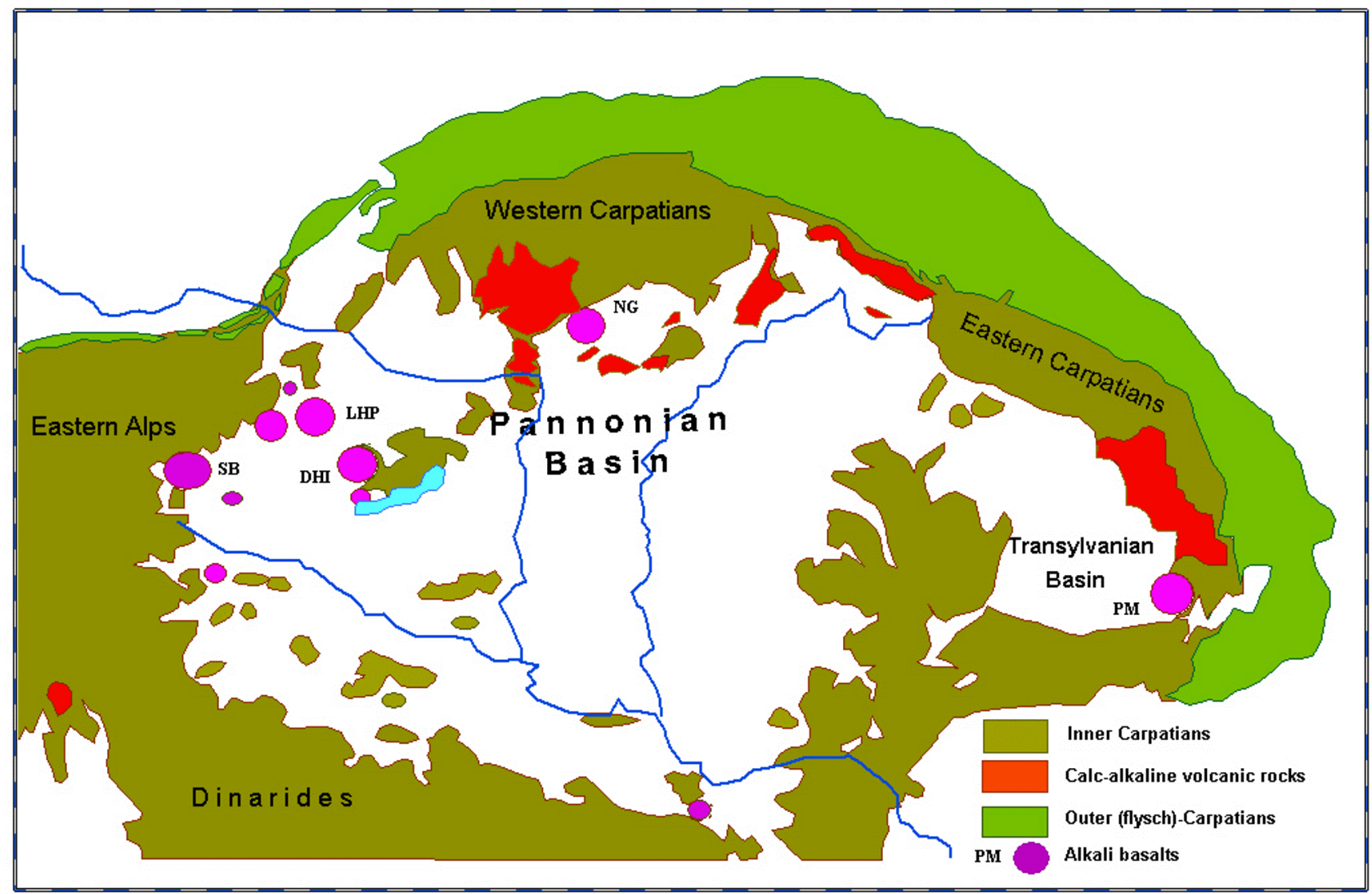

Figure 1. The tectonic scheme of the Carpathian-Balkan region [Falus et al., 2000]: PM - Persani Mountains; LHP - Little Hungarian plain; SB - Stirian Basin; BBH - Bakony-Balaton Highland Volcanic field (Hungarian Midmountains); NG - Nograd-Gomor Volcanic field.

ern Hellenides. However, the problem of boundaries of the Rhodope and Serbian-Macedonian massifs is debatable: based on findings of Tertiary granites in the Rhodope Massif, some researchers attribute it, as well as part of the SerbianMacedonian massif, to the Hellenides.

Of the aforementioned elements of the present-day structure, the CBR structure is most intricate (some parts of the region differ in their development history).

The Outer Carpathians and Carpathian foredeep form a continuous arc, and the Inner Carpathians consist of individual blocks the relations between which are still open to question (e.g. the Apuceni Mountains and the Southern Carpathians). The Inner Carpathians override the Outer Carpathians along a system of thrusts occasionally developing into nappes and varying in number throughout the arc; the overthrusting time also varies (from the Early Cretaceous to the beginning of Cenozoic) [Birkenmaier, 1977; Khain, 1984; Tectonics of Europe ..., 1978; and others].

The structure of the Outer Carpathians is represented by a combination of folds and nappes of up to $1200 \mathrm{~km}$ in length and $100 \mathrm{~km}$ in width, with thrust motions being directed toward the West and East European platforms. Most researchers of the Carpathians believe that the overthrusting started in the Oligocene and ended at the Sarmatian time [Khain, 1984; Machel, 1974; and others]. The amount of crustal shortening due to the folding and overthrusting varies from $20-30$ to $100-120 \mathrm{~km}$ according to estimates of various authors.

The entire Carpathians are separated from the adjacent platform by a foredeep developed on the pre-Alpine heterogeneous basement. The foredeep has been shown to migrate northeastward within the Eastern Carpathians. Deep drilling and DSS results [Sovchik, 1984] indicate that the platform margin plunges toward the northern slope of the Ukrainian Carpathians. The foredeep is narrowest in the junction zone between the Carpathians and the Bohemian Massif (a few kilometers) and widest in the Western and Southern Carpathians (up to $200 \mathrm{~km}$ ). The thickness of deposits varies from $2 \mathrm{~km}$ in the Western Carpathians to $5 \mathrm{~km}$ in the Ukrainian Carpathians and to 8-10 km in the Southern Carpathians.

The Pannonian basin was considered for a long time as a median mass, but a bulk of new data including drilling results showed that the pre-Neogene basement is characterized by strong heterogeneity and consists of rocks varying in composition and age [Balla, 1984]. Destruction of the continental crust at the end of Triassic gave rise to an oceanic basin a few hundred kilometers wide. Its closure in the Early 
Cretaceous resulted in the formation of a new metamorphic granite layer and, as early as the middle of the Late Cretaceous, a considerable part of the present-day Pannonian depression was a stable region within which epicontinental sea basins were developed. Pre-Neogene complexes of the Pannonian basin contribute to the structure of the Carpathian arc and extend into Dinarides in the south.

The Dinarides continue the Southern Alps to the southeast; the boundary between them is somewhat unclear and is marked by the appearance of ophiolites. The Dinarides are separated by a steep fault from the Eastern Alps and plunge under Neogene deposits of the Pannonian basin in the north. The Rhodope and Serbian-Macedonian massifs separate the Dinarides from the Carpathian-Balkan arc.

The orogeny within the Balkanides started at the postSarmatian time, as is evident from the Pliocene-Quaternary molasse unconformably overlying pre-Meotian rocks (Sarmatian and older ages) [Malovitskii, 1979; Vaptsarov et al., 1990]. A system of narrow, linearly elongated ranges of Stara Planina with uplift add of more than $1000 \mathrm{~m}$ is bounded by the Nizhne-Kamchiiskii trough to the north and by the Burgas depression to the south; the downwarp add in the latter exceed 700 m [Southern Black Sea ..., 1985].

As distinct from both the Alps and Carpathians, a main geological-structural feature of the Dinarides is the wide occurrence of ophiolites, which serves as a basis for the subdivision of Dinarides into two major zones, inner and outer. The present-day nappe-fold structure of Dinarides started to form at the Middle/Late Eocene boundary and ended in the Early Miocene. By that time, horizontal movements of nappes had stopped in both the inner and outer zones, and subsequent tectonic movements were mainly vertical.

The neotectonic stage in the Carpathian region began at the Pannonian time (sensu stricto), i.e. 11-10.5 Ma [Grachev, 2000; Grachev et al., 1987a], when peripheral basins (Vienna, Transylvanian, and others) died away within the Carpathian structural plate and horizontal movements of nappes stopped in both outer and inner zones of the Carpathian arc. By that time, the Carpathian structural loop had already existed in its present-day outlines [Burtman, 1984]. Beginning from the Pannonian Age, vertical crustal movements forming the contemporary topography prevailed within the Carpathian loop. However, there exist data indicating that horizontal movements persisted as long as the end of the early Pannonian in some areas of the Pannonian basin including the Mecsek Mountains, where Sarmatian deposits override Lower Pannonian rocks [Kleb, 1973]. Another example is the northeastern part of the Pannonian basin (Eastern Carpathians), where compression conditions have been preserved until present time according to instrumental data [Brimich and Latynina, 1988]. Finally, an area of this type is located in the southeasternmost Southern Carpathians at the Transylvanian basin/Moesian platform junction including the Vrancea zone. Here, many data yield evidence of convergence between the Transylvanian (Tisa-Dacian) block and the Eurasian plate [Hippolyte et al., 1999] including the Pliocene-Quaternary calc-alkalic volcanism [Chalot-Prat and Girbacea, 2000].

Vertical deformations in Carpathians are well constrained by the present hypsometric position of the Polonin peneplain
Table 1. Matrix of factor loads for main parameters of the Carpathian-Balkan region

\begin{tabular}{|l|ccc|}
\hline \multirow{2}{*}{ Parameter } & \multicolumn{3}{|c|}{ Factors } \\
\cline { 2 - 4 } & 1 & 2 & 3 \\
\hline$V_{\mathrm{r}}, \mathrm{mm} / \mathrm{yr}$ & 0.83 & 0.17 & -0.14 \\
$N, \mathrm{~m}$ & 0.88 & -0.09 & -0.31 \\
$M, \mathrm{~km}$ & 0.81 & -0.16 & 0.50 \\
$q, \mathrm{~mW} / \mathrm{m}^{2}$ & -0.78 & 0.43 & -0.22 \\
Factor weight, $\%$ & 61.5 & 15.7 & 7.8 \\
\hline
\end{tabular}

dated at the early Sarmatian by the analysis of correlate deposits [Tsys, 1970]. A similar conclusion was drawn by other authors [Planation Surfaces ..., 1973]. This surface forms the top level of Carpathians below which younger planation surfaces and a series of river terraces have developed [Zuchiewicz, 1990]. Carpathian uplift amplitudes vary from 300-400 $\mathrm{m}$ in the inner zone of the Carpathian arc (Matra, Bakony and other mountains) to $1500 \mathrm{~m}$ in its outer zone. Many neotectonic and geodynamic features of the arc are associated with the development of the Pannonian basin.

Factor and trend analyses of amplitude variations of recent $\left(V_{r}\right)$ and neotectonic $(N)$ movements, heat flow $(q)$ and crustal thickness $(M)$ were performed in order to elucidate main geodynamic and neotectonic relationships in the CBR [Bronguleev et al., 1984; Grachev, 2000; Magnitsky et al., 1988].

The factor analysis (Table 1 ) revealed, on a regional scale, a stable inverse correlation of heat flow with all other parameters (factor 1 has a weight of more than 60\%) and the presence of CBR areas where the heat flow is inversely proportional to the recent and neotectonic movements. Moreover, factor 2 suggests the presence of areas where, in contrast to the regional relationship (factor 1 ), the crustal thickness is inversely correlated with neotectonic movement amplitudes. The factor analysis generally implies that the thermal heating of the lithosphere is the main factor responsible for the crustal thinning, as well as for the recent and neotectonic activity in the most territory of the CBR.

Results of the trend analysis of the same variables as in Table 1 provide a graphic illustration of the relationships constrained by the factor analysis. Regional components of recent and neotectonic movements (Figure 2) indicate the presence of a vast CBR minimum encompassing the Pannonian depression proper and peripheral subsidence areas (Vienna, Transylvanian, Transcarpathian, and Trans-Danube basins). The minimum also includes the Hungarian Midmountains (Bakony Mountains). Another minimum, substantially smaller in size, includes the Mysian plate and adjacent offshoots of Southern Carpathians.

Regional maximums of the same variables nearly coincide in area and encompass the Western, Eastern and Southern Carpathians, part of the Eastern Alps, Dinarides, and the Apuseni Massif separating the Pannonian and Transylvanian basins. Comparison of regional trends in the four variables $\left(V_{r}, N, q\right.$ and $\left.M\right)$ clearly indicates that their areal variations are correlated; namely, regional components of recent and 

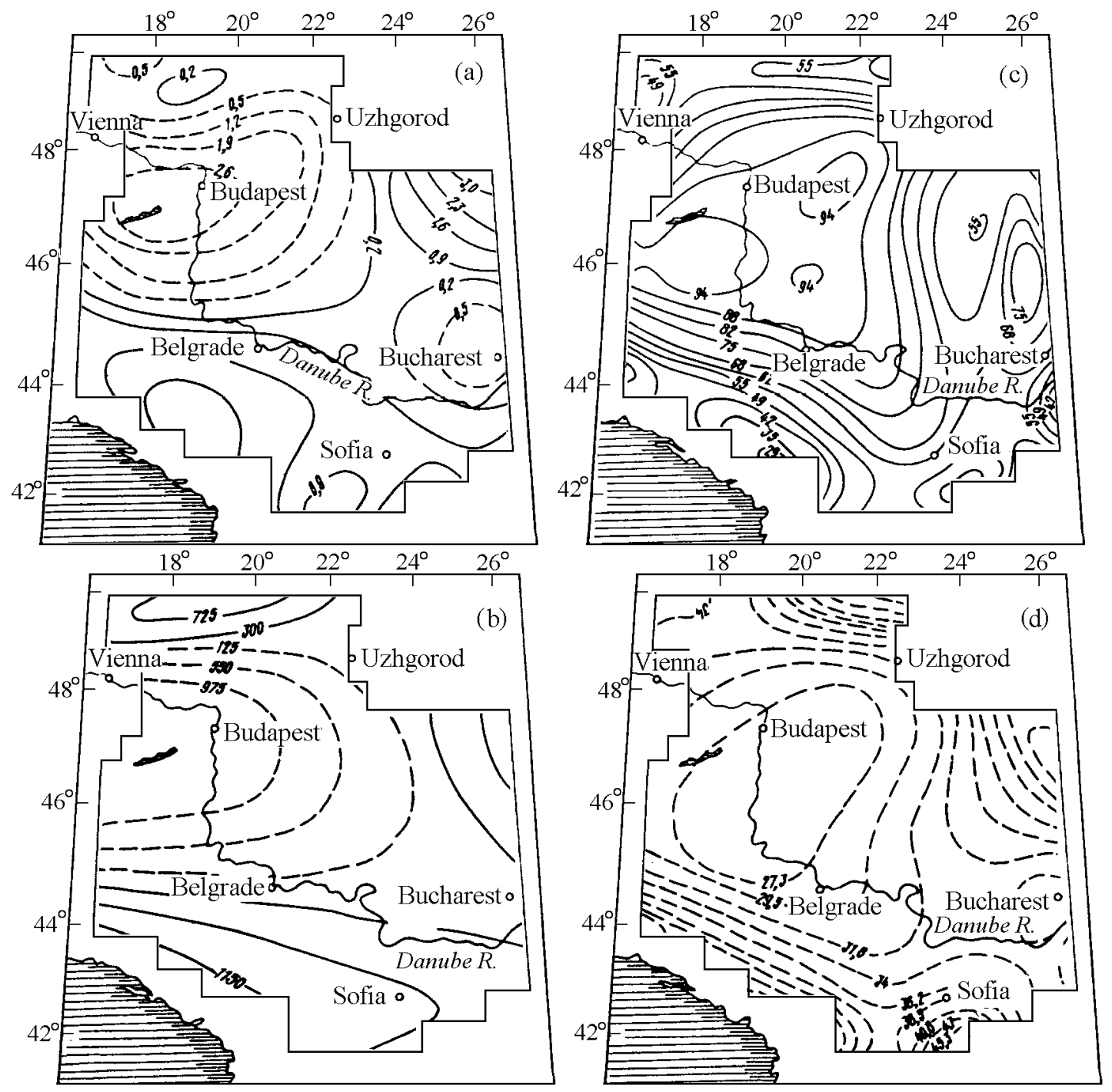

Figure 2. Regional components of the (a) recent crustal movement velocity, (b) neotectonic movement velocity, (c) heat flow and (d) Moho depth. Broken lines are contours of negative values [Magnitsky et al., 1988].

neotectonic crustal movements and Moho depths vary inversely proportional to the regional component of the heat flow.

Analysis of local components of the same variables showed that they are much less correlated (Figure 3), as could be expected from the results of the factor analysis (Table 1).

The best agreement is observed for the recent and neotectonic movements. Best resolved are some structures in the central and southwestern CBR. Among uplifts, these are the Hungarian Midmountains, Apuseni Massif, Dinarides and Eastern Carpathians, whereas subsidence areas of this type are the Great Hungarian Lowland, Transcarpathian and Transylvanian and Vienna basins. Other local components are less correlated, although the correlation is good in some CBR areas (Figure 3).
Thus, recent crustal movements within CBR are characterized by high degree of inheritance from neotectonic movements (much higher than in platform regions) [Magnitsky et $a l ., 1988]$. The movements are characterized by inheritance both on the scale of the entire region and in individual areas on a scale of $10^{4}-10^{5} \mathrm{~km}^{2}$.

Grachev et al. [1987a] noted that the main factor responsible for variations in the neotectonic activity within the CBR is the thermal heating of the lithosphere. Actually, the temperature distribution at Moho (Figures 4 and 5) indicates that the Moho temperature is highest in the Pannonian basin, Czechian-Silesian arc, Eastern Carpathians and Carpathian foredeep $\left(T_{\mathrm{M}}\right.$ of more than $\left.750^{\circ} \mathrm{C}\right)$, where about $70 \%$ of the observed heat flow are of mantle origin [Cermak and Bodri, 1986]. The $T_{\mathrm{M}}$ temperature in the Transylvanian 

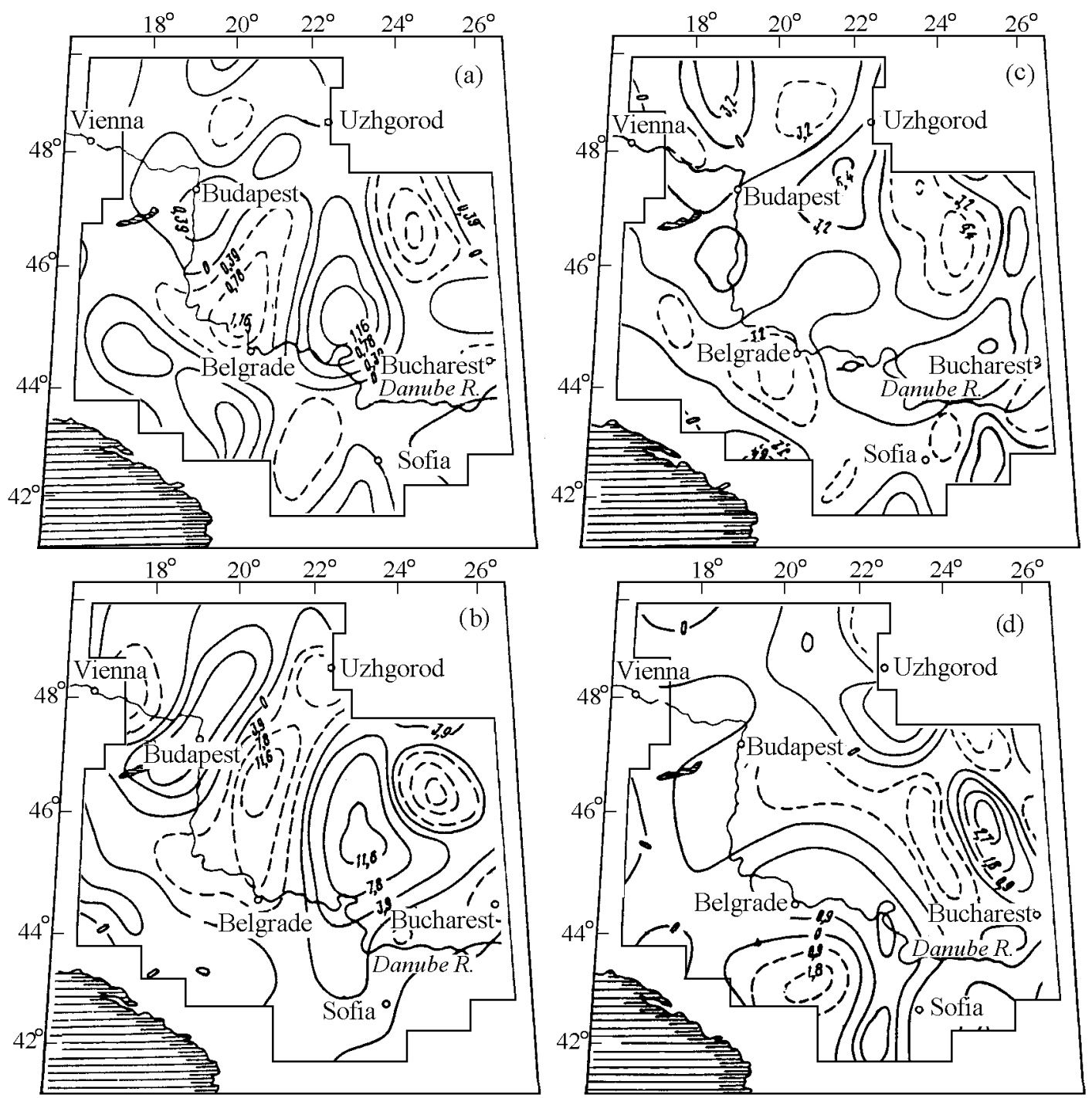

Figure 3. Local components of the (a) recent crustal movement velocity, (b) neotectonic movement velocity, (c) heat flow and (d) Moho depth. Broken lines are contours of negative values [Magnitsky et al., 1988].

basin is about $500^{\circ} \mathrm{C}$, which is close to the values obtained for the Moesian plate. The $T_{\mathrm{M}}$ temperature is about 500 $600^{\circ} \mathrm{C}$ under the Dinarides and Western Carpathians.

Thus, the calculated distribution of temperatures at the crust base reveals three heating regions in the lithosphere with a high mantle heat contribution: the Pannonian basin, Czechian-Silesian arc and junction zone of the Western and Eastern Carpathians. These are exactly the areas of the active Pliocene-Quaternary volcanism. However, the analysis of the temperature distribution both at the Moho and in deeper lithosphere layers reveals distinctions between the areas noted above.

The $1000^{\circ} \mathrm{C}$ isotherm lies at depths of $30-32 \mathrm{~km}$ under the Pannonian basin and 50-55 km under the Bohemian Massif (Figure 4). These data are well consistent with independent results of magnetotelluric sounding indicating the presence of a high electrical conductivity zone at depths of $60 \mathrm{~km}$ under the Pannonian basin and 90-100 km under the Czechian Massif [Adam et al., 1977, 1989; Lithosphere ..., 1993; Marton, 1999; Onuoha, 1981].

The third area of higher Moho temperatures is located in the Eastern Carpathians where a high electrical conductivity is observed at depths of $15-20 \mathrm{~km}$ rather than in the mantle [Adam et al., 1989; Lithosphere ..., 1993] and is an order of magnitude lower than under the Pannonian basin. This does not contradict the possible existence of crustal melting sources associated with which the young calc-alkaline volcanism.

Thus, as distinct from other CBR regions, the neotectonic geodynamics of the Pannonian basin is characterized by a 


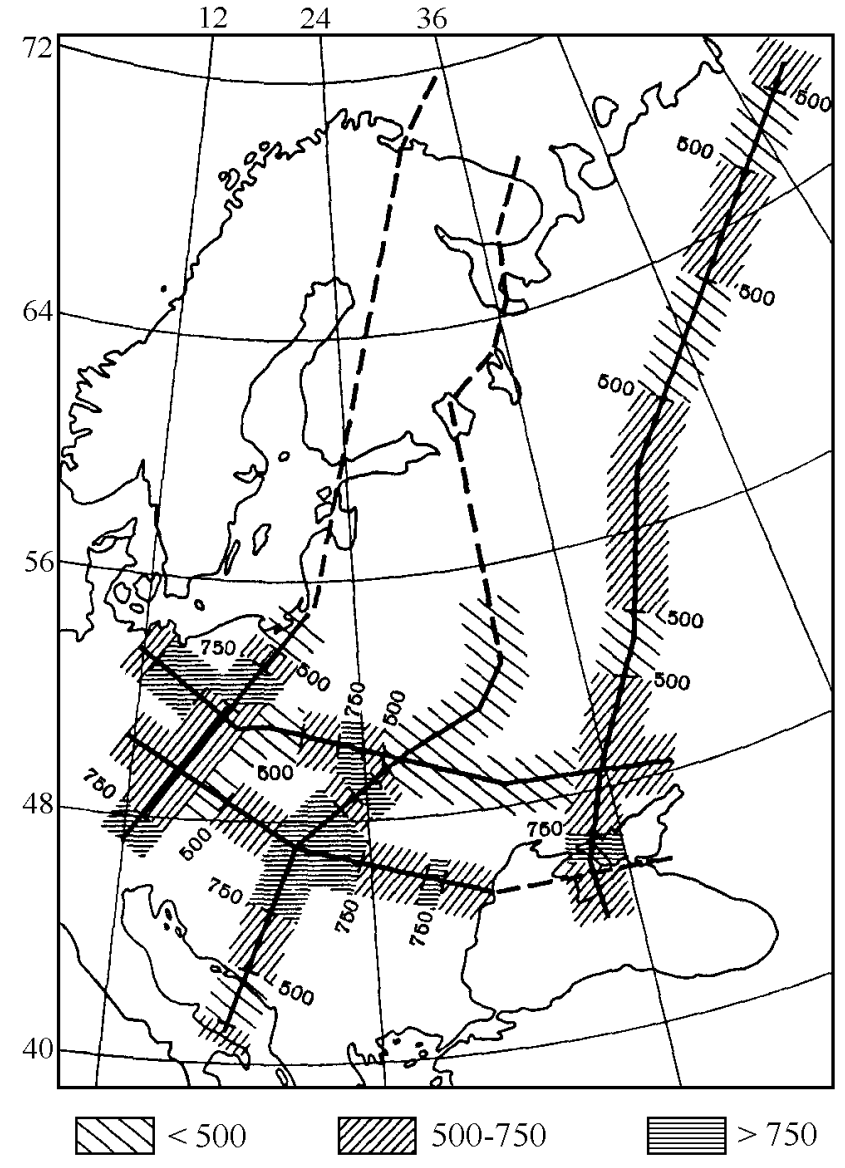

Figure 4. Moho temperature $\left({ }^{\circ} \mathrm{C}\right)$ in the CarpathianBalkan region and adjacent areas [Cermak and Bodri, 1986].

well-pronounced thermal control responsible for the main features of its recent and neotectonic geodynamics [Grachev, 2000].

\section{Neotectonics of the Pannonian Basin}

Pannonian basin was considered for a long time as a classical example (tectonotype) of a median mass within the Alpine fold region. Such ideas had existed until the early 1970 s when the creation of plate tectonics resulted in a revision of many concepts in the Earth sciences including the ideas concerning the Alpine foldbelt development.

Modern models of the Pannonian basin development mostly invoke plate tectonics ideas in order to account for the evolution of the Alpine belt [Smith, 1971 and many others]. These works were the first attempts to use the plate tectonics for interpreting the evolution of the entire Alpine foldbelt. They initiated the development of more detailed kinematic schemes for various parts of the Alpine belt in order to account for the formation of the system of basins in the Pannonian region on the basis of both the kinematics of the Carpathian structural loop and the thermal model of
McKenzie [Burchfiel and Royden, 1982; Royden and Sclater, 1981; Royden et al., 1983a, 1983b; Sclater et al., 1980].

Some authors regarded the Pannonian basin as an ensialic downwarp that arose behind the subduction zone [Bleahu et al., 1973; Boccaletti et al., 1976; Horvath and Stegena, 1977]. In particular, the analogy with the development of the Great Basin in the western U.S. was used in the Scholz model [Scholz et al., 1971], which retains its significance even now.

All of the aforementioned works the plate tectonic approach, interpreting (from the standpoint of kinematics rather than geodynamics) the formation of basins within the Carpathian structural loop in terms of extension related to shear deformations resulting in the formation of pull-apart basins.

It is easy to see that, within this approach, the same kinematic group includes basins of various ages whose development was concurrent with the collision of lithospheric plates (peripheral downwarps such as the Vienna, Transcarpathian and other basins) or postdated it (the system of inner basins of the Late Miocene-Pleistocene, i.e. the Pannonian stage of development). The formation of the Transylvanian basin remains altogether unaccounted for.

The above models, in terms of which the Pannonian basin developed as a postrift sedimentary basin throughout the Late Miocene-Quaternary, are purely kinematic. They fail to account for the strong heating of lithosphere and alkalibasaltic volcanic activity, seismicity, synsedimentary mode of listric faulting and several other geological and geophysical facts [Badawy et al., 2001; Bus et al., 2000; Csontos, 1995; Grachev, 2000; Grachev et al., 1987a, 1987b].

In the late 1980s, the entire complex of data was used for seismic regionalization resulting in the construction of an $M_{\max }$ map predicting the seismic hazard in the Paks nuclear power plant (NPP) area [Grachev et al., 1987c, 1989b]. These studies did not confirm the existence of a young (Quaternary) strike-slip fault (previously supposed by several Hungarian specialists) in this area and initiated the organization of new investigations [Seismic Safety ..., 1997]. It was shown that there is no evidence supporting the presence of any Quaternary faults in the Paks NPP area [Seismic Safety ..., 1997, p. 192].

A basically different approach to the interpretation of development of the Pannonian basin and surrounding Carpathian mountains was elaborated in [Grachev, 1987a, 2000; Grachev and Dobrzhinetskaya, 1987; Grachev et al., 1987a, 1987b, 1989a, 1992]. Based on the entire complex of geological and geophysical data (including the seismicity analysis), this approach interprets the development of basins within the Carpathian loop since the Pannonian time in terms of the synorogenic rifting control.

Subsequent studies provided new evidence, both geological and geophysical, in favor of the model proposed. Thus, detailed observations of faults in the Gerecse Mountains (northwestern Pannonian basin) showed that fractures and normal faults trending NNE-SSW cut all rocks of the Sarmatian and younger ages [Bada et al., 1996]. This has led to the conclusion that the given region is under conditions of extension oriented NW-SE. New field investigations in north-eatern part of basin during the last 2 years (2001 and 
(a)

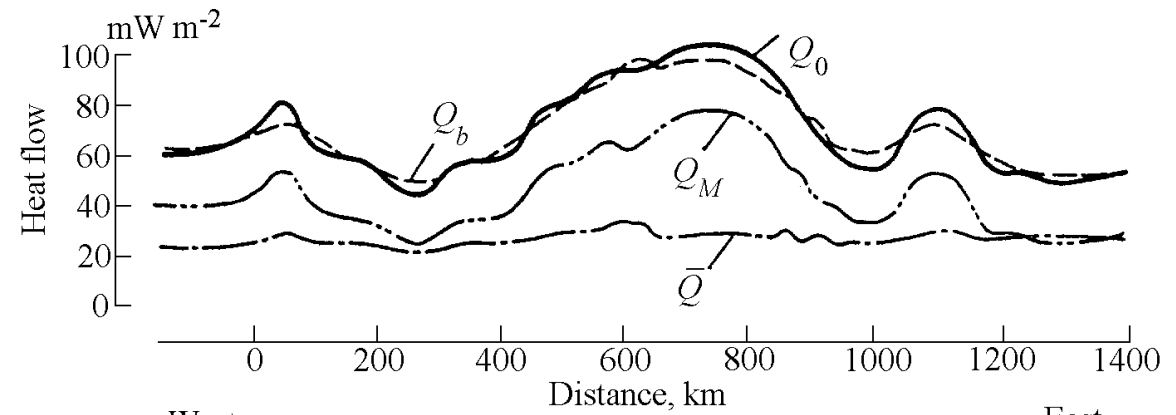

(b)

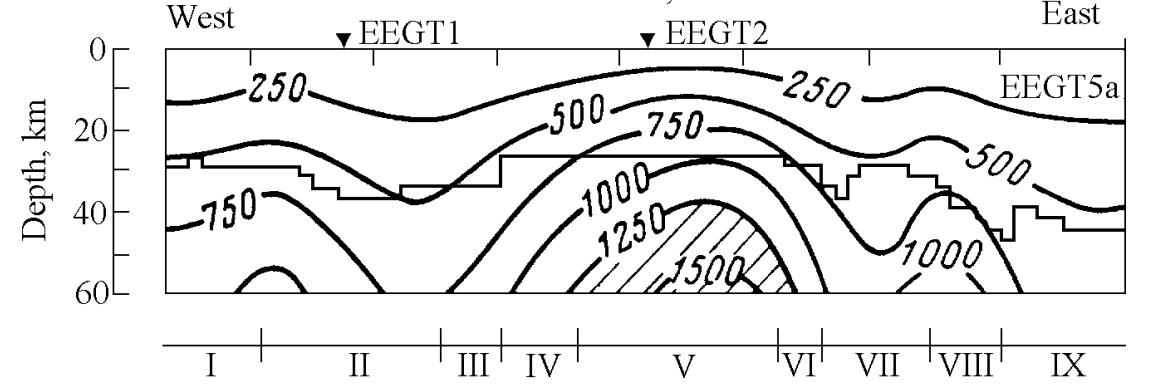

Distance, $\mathrm{km}$

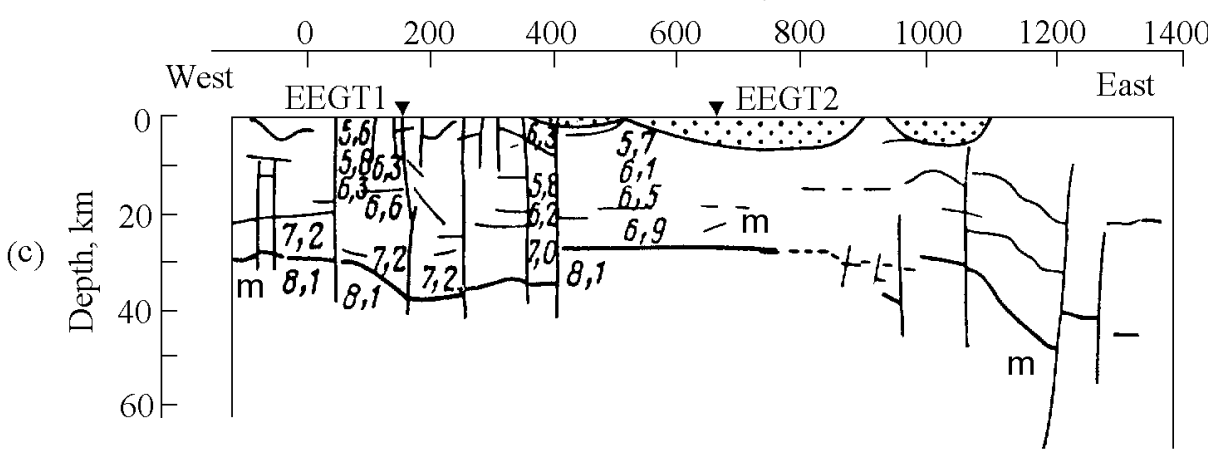

Figure 5. (a) Heat flow, (b) estimated temperature distribution in the lithosphere and (c) seismic cross section along the EEGT-5 international geotraverse in the Carpathian-Balkan region [Cermak and Bodri, 1986]. $Q_{\mathrm{o}}$ and $Q_{\mathrm{b}}$ are observed and estimated values of the heat flow, respectively; $Q_{\mathrm{m}}$ is the contribution of mantle sources of the lithosphere heating; and $Q$ is the contribution of radiogenic sources in the crust. I, Saxony; II, Bohemian Massif; III, Outer Western Carpathians; IV, Inner Western Carpathians; V, Pannonian basin; VI, Apuseni Massif; VII, Transylvanian basin; VIII, Eastern Carpathians; IX, Moesian plate.

2002) allow to get a lot of data suggested this conclusion.

Another important aspect relates to new data on the deep structure of the Pannonian basin that updated the Moho depths and yielded a lower estimate of the Moho $P_{\mathrm{n}}$ velocities [Weber, 2002].

\section{Main Characteristics of the Pannonian Basin Neotectonics}

Neotectonic movement amplitudes in uplift areas were determined by the method of trend analysis (nonpolynomial modification) [Grachev and Mishin, 1975] applied to the hyp- sometric position of the early Sarmatian planation surface taking into account the amount of denudation varying from 50 to $150 \mathrm{~m}$ in Bakony, Bukk, Matra and other mountains [Aron, 1980].

Neotectonic movement amplitudes in subsidence areas were found from the thickness and facies analysis of Pannonian and Quaternary deposits using the known procedure of introducing corrections for variations in the porosity and density with depth [Steckler and Watt, 1978]. Since we had data from nearly all stratigraphic holes crossing the Pannonian sedimentary cover, as well as seismic reflection and common midpoint data, neotectonic movement amplitudes were for the first time correctly estimated throughout the Pannonian basin. A fragment of the neotectonic map of the Pannonian basin is presented in Figure 6 . 


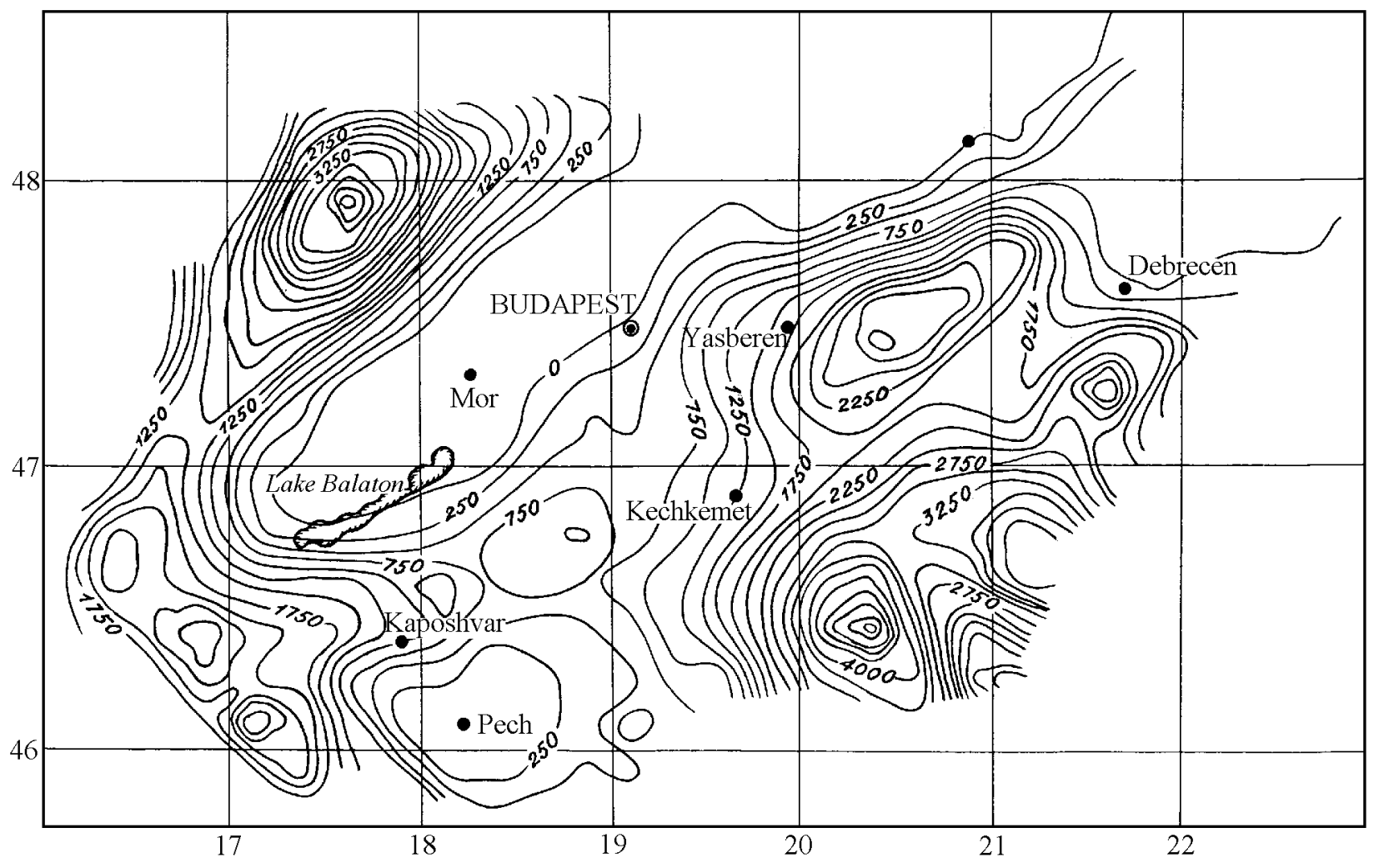

Figure 6. A fragment of the neotectonic map of the Pannonian basin (see explanations in text).

Analysis of subsidence curves in various areas of the Pannonian basin constructed by the aforementioned technique (Figure 7) leads to conclusions vital for the neotectonics and geodynamics. The subsidence of peripheral basins inside the Carpathian loop continued from the beginning of Miocene to the end of the Sarmatian, after which the basins virtually stopped their development; on the contrary, inner basins of the Pannonian region started their development just from this time, i.e. from the beginning of the Pannonian Age sensu lato (Figure 7). The behavior of the subsidence curves indicates strong differentiation of neotectonic movements in areas of prevailing subsidence. Even this circumstance alone precludes the classification of the study region as a sedimentary postrift basin because, according to the McKenzie model. The sedimentary cover thickness in such basins varies weakly.

As is evident from the neotectonic map (Figure 6), all structures of the Pannonian basin are elongated in the NESW direction in accordance with the so-called Balaton direction. An exclusion is two troughs in the southeast of the region known under the names Mako and Bekes. Their development at the Pannonian stage occurred in places of deep (about $1000 \mathrm{~m}$ ) basins, relicts of a Sarmatian basin, and was associated with the isostatic subsidence due to the accumulation of sediments supplied by rivers (Figure 8, 9), as has recently been established from facial analysis of seismostrati- graphic and deep drilling data [Mattick et al., 1985]. The formation mechanism of this type of basins was described in [Grachev and Mikhailov, 1988].

Two uplift areas are recognizable in the Pannonian basin. The first extends from the Hungarian Midmountains (the Bakony Mountains in the Lake Balaton area) through the Matra and Bukk mountains in northeastward direction toward the Eastern Carpathians. The uplift amplitudes vary from $300 \mathrm{~m}$ in the southwest to $800 \mathrm{~m}$ in the northeast; the $19^{\circ} \mathrm{E}$ meridian approximately divides the area into two parts: the western zone of neotectonic syndenudatinal uplift and the northeastern zone of synerosional uplift.

In the first case, uplifts are compensated by denudation, and in the second case they are not, which is reflected in both the topography and neotectonic movement amplitudes. The Bakony Mountains represent a typical polygenetic planation surface whose monotonic topography is disturbed by chains of cinder and lava cones with elevations of 300-400 m. Volcanic structures are built on the pre-Pannonian basement, and lava flows are interbedded with Pannonian deposits, which indicates a young age of the eruptions.

Neotectonic deformations are best expressed as displacements of lake terraces on the northeastern coast of Lake Balaton, whereas traces of neotectonic deformations in inner part of the Bakony Mountains are recognizable only in quarries in Pannonian deposits. 

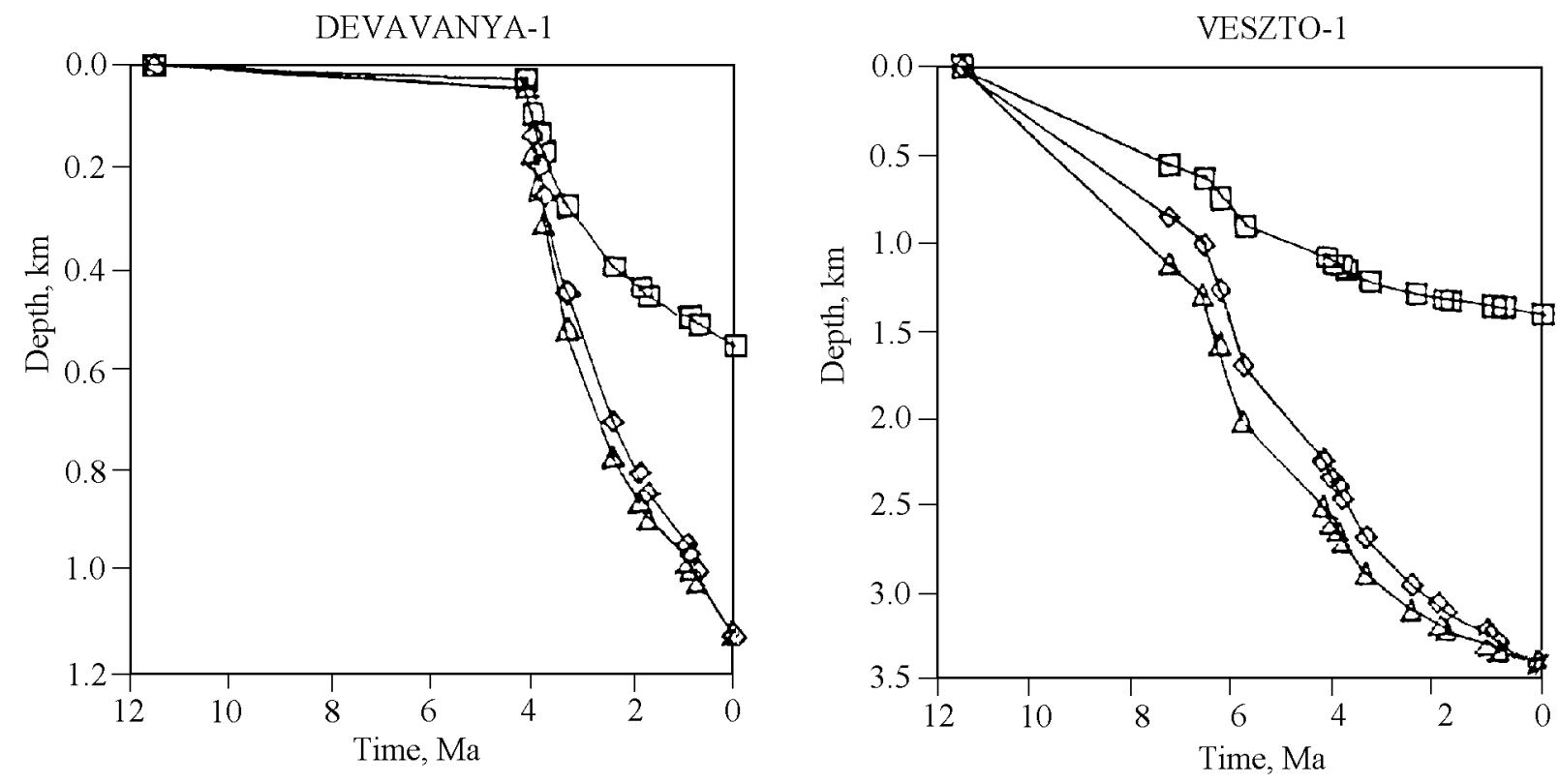

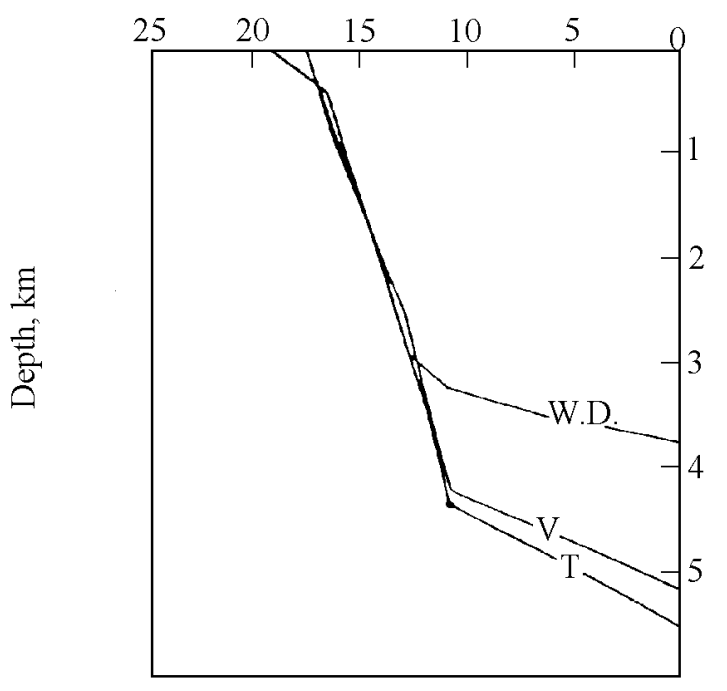

Time, $\mathrm{Ma}$

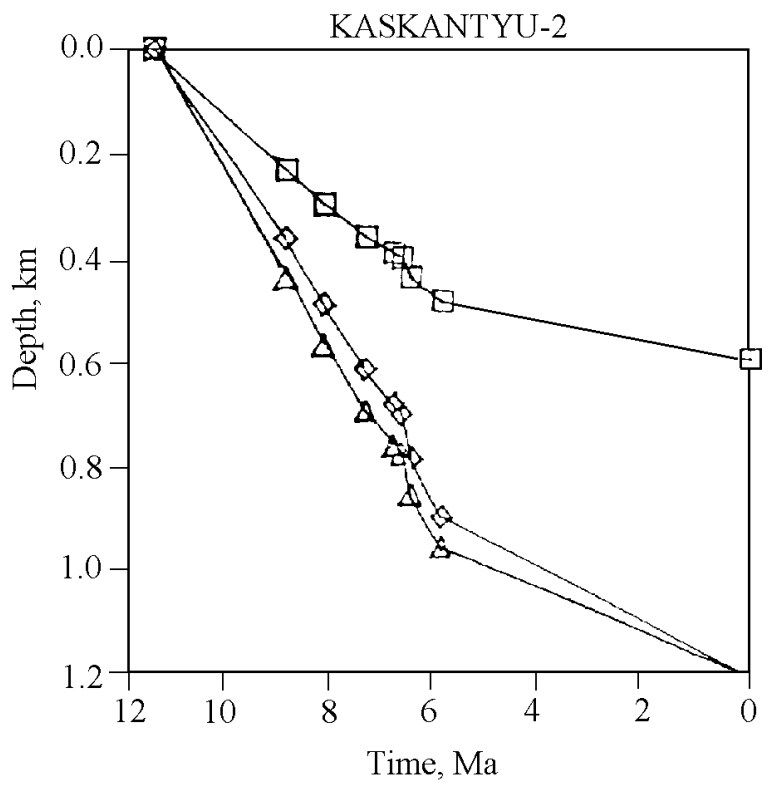

Figure 7. Curves of tectonic subsidence in the eastern Pannonian basin, constructed on the borehole data: triangle - thickness of sediments without correction for porosity; rhomb - the same, with correction for porosity; square - the same, with correction for isostatic factor. Subsudence curves for for Transcarpathian (T), Vienna (V) and West Danube (W.D.) basin are shown for compariosn [Sclater et al., 1980].

Pannonian deposits are typically cut by systems of large open joints and microscopic normal faults with amplitudes of up to $1 \mathrm{~m}$ (Figure 10). The concentration of the joints reaches of 3-4 per $1 \mathrm{~m}$ of length, and their predominant strike is the Balaton (NE) direction.

A system of steep normal faults dipping at an azimuth and angle of SW246 $6^{\circ}$ and $62^{\circ}$ with well-observable mullion structures was discovered and described by the author in 1987 on the western periphery of the Bukk Mountains (near the Homokteren village) in strongly cemented sands of the Upper Oligocene. Another system is represented by subvertical joints $5-10$ to $20 \mathrm{~cm}$ wide filled with uncemented sand. Such a character of the joints makes them similar to neptunian dikes (Figure 11). 


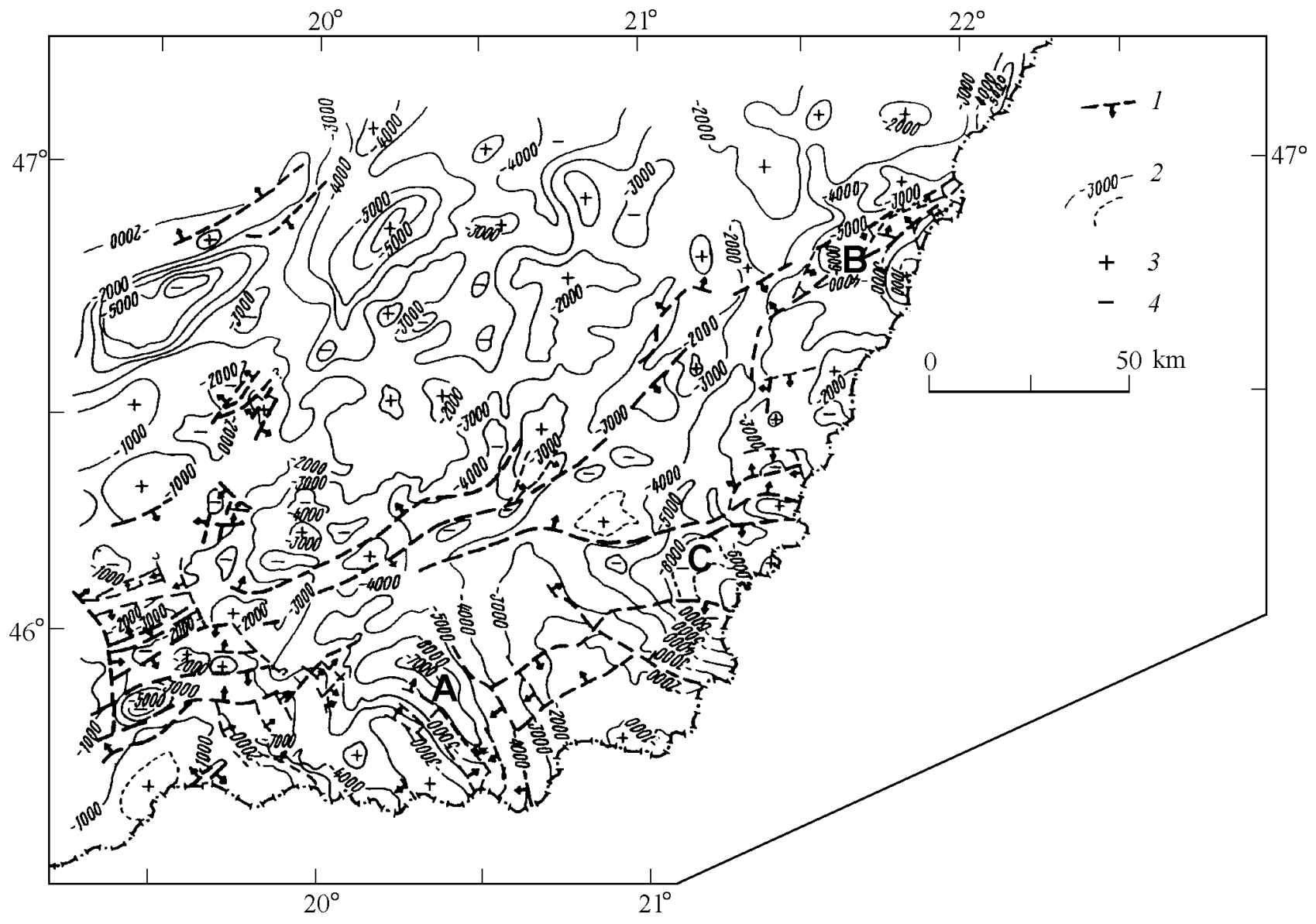

Figure 8. Structural map of the Cenozoic base in the southeastern part of the Pannonian basin [Mattick et al., 1985]: (1) fault attitudes (arrows show the dip direction of fault plane); (2) depth contours with a 1000-m interval (the broken line shows a 500-m interval); (3, 4) local uplifts and subsidences of the pre-Cenozoic basement); (5) subbasins: (A) Mako, (B) Derecke and (C) Bekes.

The second uplift area is located south-southeast of Lake Balaton in the Mecsek Mountains forming a synerosional brachyanticline in the basement with movement amplitudes of up to $400-500 \mathrm{~m}$. The northern and southern boundaries of this area are thrown up along systems of ENE-striking faults. The hinge of the fold gently dips in SW and NE directions.

Investigations in numerous deep quarries in the vicinities of the Mecsek Mountains have revealed a widely developed system of step-like listric normal faults dipping at $\mathrm{E} 90^{\circ}<40$ $60^{\circ}$ and having an overall amplitude of vertical motions of up to 5-6 m. Importantly, exposures of Sarmatian limestone are observed at a distance of $100 \mathrm{~m}$ from Pannonian outcrops, and these deposits are likely to contact each other on a fault.

We noted above that, unlike other regions of Hungary, deformations of the crust in the Mecsek Mountains changed from compression to extension in the early Pannonian, and exactly from this time this uplift area was expressed in the topography.
Neotectonic subsidence amplitudes in the Pannonian basin are much greater than the uplift displacements. Two subsidence areas are clearly recognizable: one coincides with the Little Hungarian Lowland (northwest of the Hungarian Midmountains) and another is located in the central part of the Pannonian basin along the median line of the basin. The subsidence areas consist of separate linearly extending neotectonic brachyanticlinal folds often forming en echelon configurations and complicated by faults.

Thicknesses of Pannonian deposits in depressions substantially differ from those in uplifts (Figure 12). As was shown for the first time by Vadas [1964] and subsequently confirmed by more detailed analyses [Grachev, 2000; Grachev et al., 1987a; Mattick et al., 1985; Pogacsas, 1984a, 1984b, 1987a, 1987b; and many others], changes in the thicknesses are accompanied by changes in the facies composition of the deposits, which is evidence of a syndepositional mode of the development of Pannonian neotectonic structural forms (Figure 12). Zones of high thickness gradients of the Pan- 

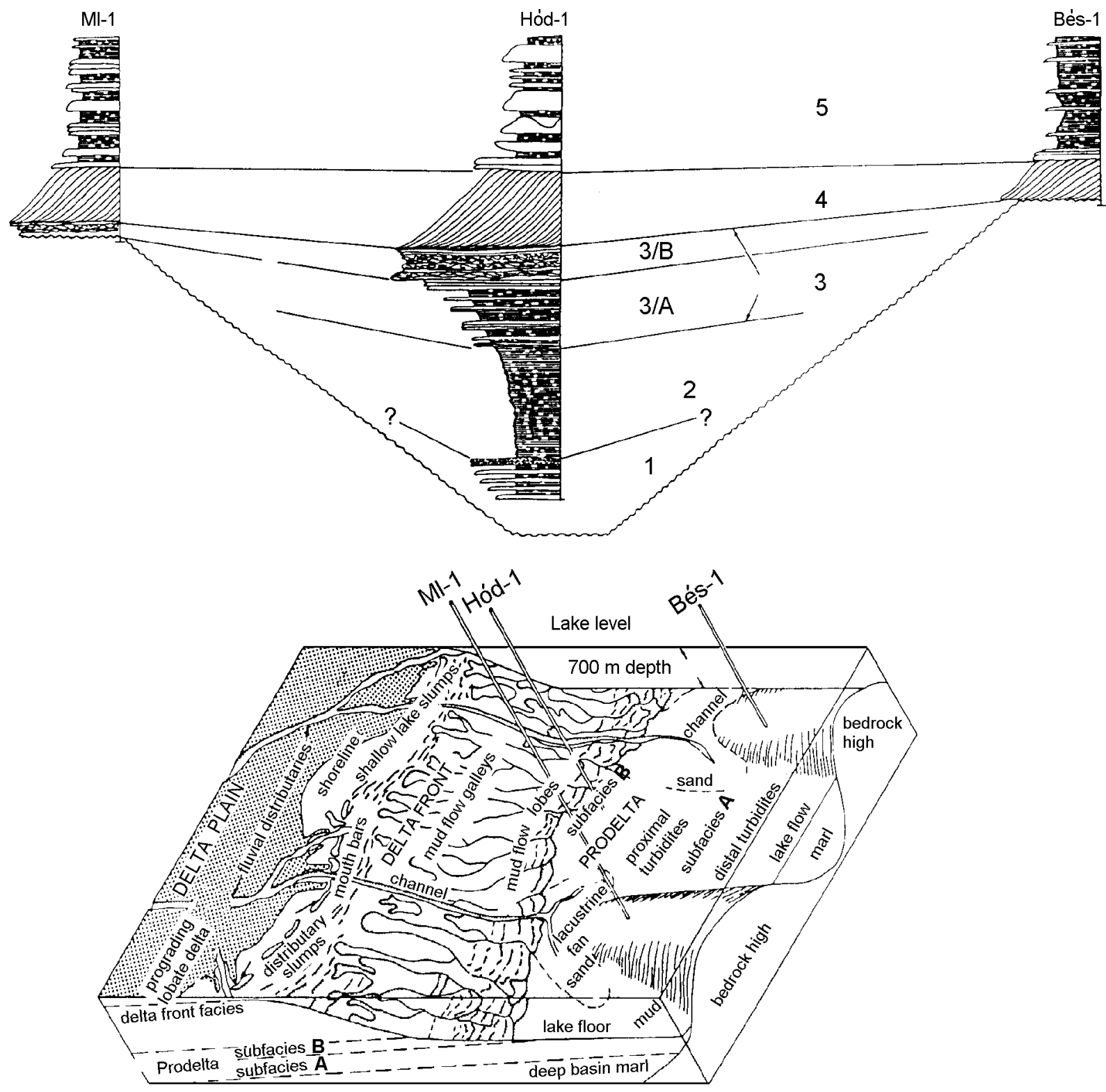

Figure 9. Facial relationships derived from cores of three boreholes drilled in the MakoHodmezevasharhei trough and on its flanks [Berczi and Phillips, 1985]: (1) basal conglomerate: (a) Paleozoic basement; (2) deep-sea facies; (3) predelta facies: subfacies A and B; (4) delta front; (5) delta plain.

nonian deposits often correlate with fractures whose origin of critical importance for geodynamics.

Data of seismostratigraphy and drillcores convincingly demonstrate that many faults involving the entire section of the sedimentary cover in inner basins of the Pannonian region can be classified as listric normal faults, which was noted for the first time by Royden and Sclater [1981]. Moreover, there is evidence indicating that such faults not only penetrate the pre-Pannonian folded basement throughout its thickness but also reach the base of the solid crust
(Figure 13) [Hajnal et al., 1996; Posgay and Szentgyorgi, 1991]. The presence of such faults is evidence that troughs developed under conditions of lithosphere extension. Such faults are known to be typical of rift areas and passive continental margins. The amount of extension in basins of the Pannonian region, as estimated from listric normal faults, occasionally reaches $20 \%$.

Two structural complexes are recognizable in the structure of the Carpathian foredeep; these are the lower complex including deposits up to the Upper Cretaceous and the 

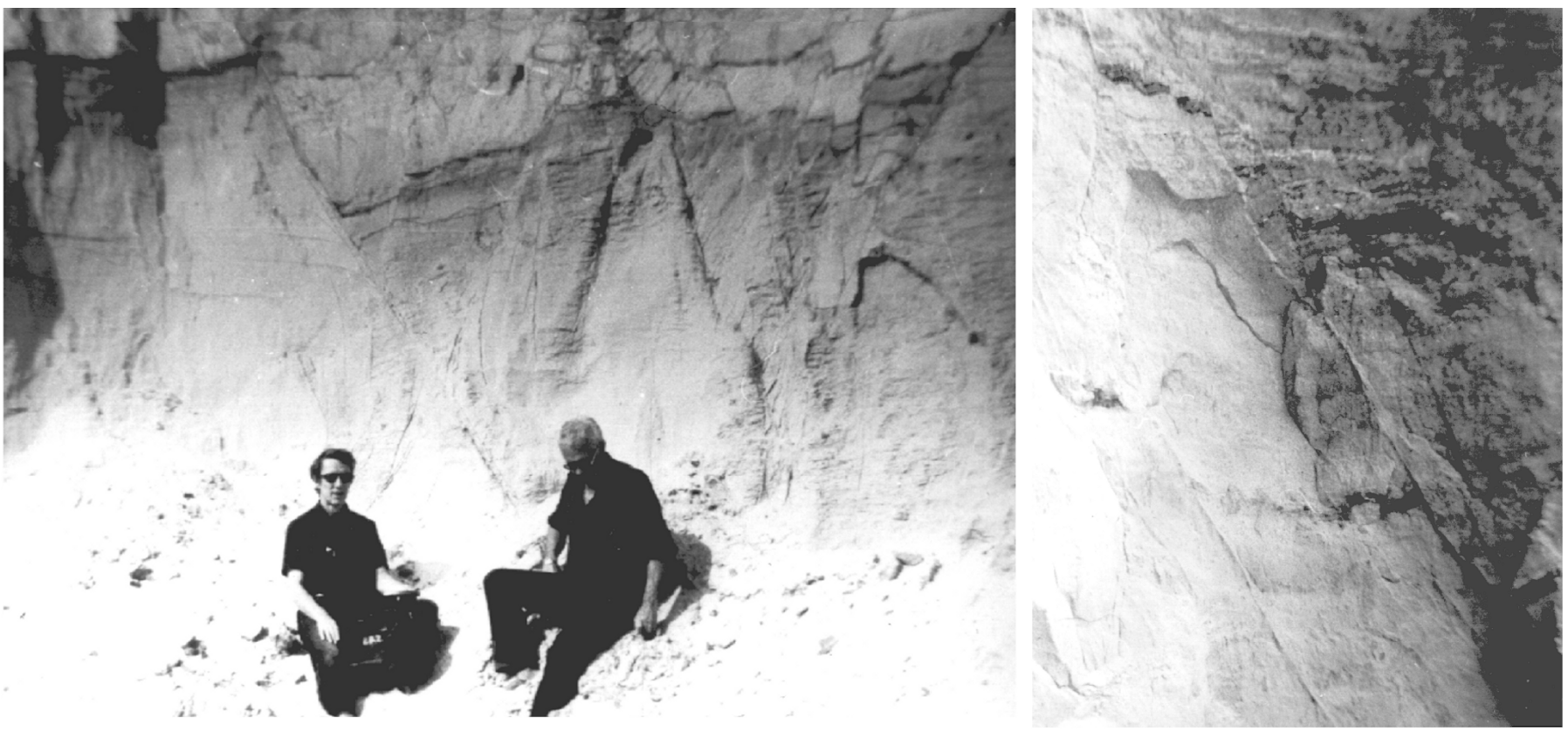

Figure 10. Faults in the Pannonian deposits (photograph by A. Grachev). A system of small normal faults in deposits of the upper Pannonian (Mt. Kish-Hedis-te, Hungarian Midmountains). Motions are largest on fault planes with a dip azimuth of $310^{\circ}$ and dip angles of $45-50^{\circ}$. It is noteworthy that Pannonian deposits are intact in the quarry wall orthogonal to the photo plane. A step normal fault in deposits of the upper Pannonian is seen to the right (a quarry in the Himeshhaza village area east of the town of Pecs).

upper one developing since the Middle Miocene, i.e. approximately at the origination time of inner basins of the Carpathian structural loop. The lower complex is distinguished by strong variability of facies in both vertical and lateral series. Conglomerates occur in the inner part of the foredeep and grade into thinner sediments toward the platform. The upper complex developed in the outer part of the foredeep, where more than 4500 m of Tortonian and Sarmatian sediments have been deposited. The rocks are weakly deformed and dip at angles of no more than $10-15^{\circ}$; syndepositional normal faults alone are developed here.

Thus, beginning from the Late Miocene, the development of the Pannonian basin cannot be considered without regard to the orogenesis in the surrounding system of Carpathians, Alps and Dinarides.

\section{Alkaline Basalt Volcanism and Its Implications for the Geodynamic Origin of the Pannonian Basin}

Analysis of volcanism is essential for understanding the geodynamics of the Pannonian basin and adjacent areas. General patterns of its development in time and space have been long established, but the implications of volcanism for tectonic development were the subject of controversy since the creation of plate tectonics.

The development of volcanism was traditionally, within

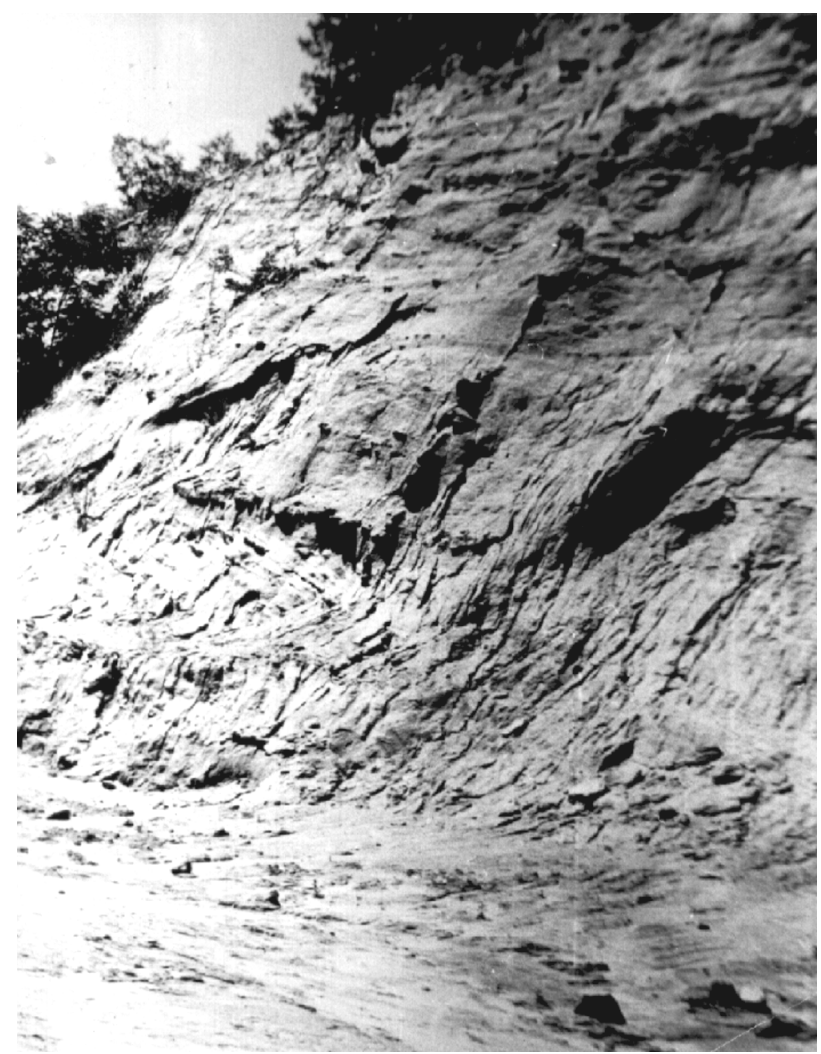

Figure 11. Neptunic dikes in Oligocene sandstones, southwestern part of Bukk Mountains (photograph by A. Grachev). 


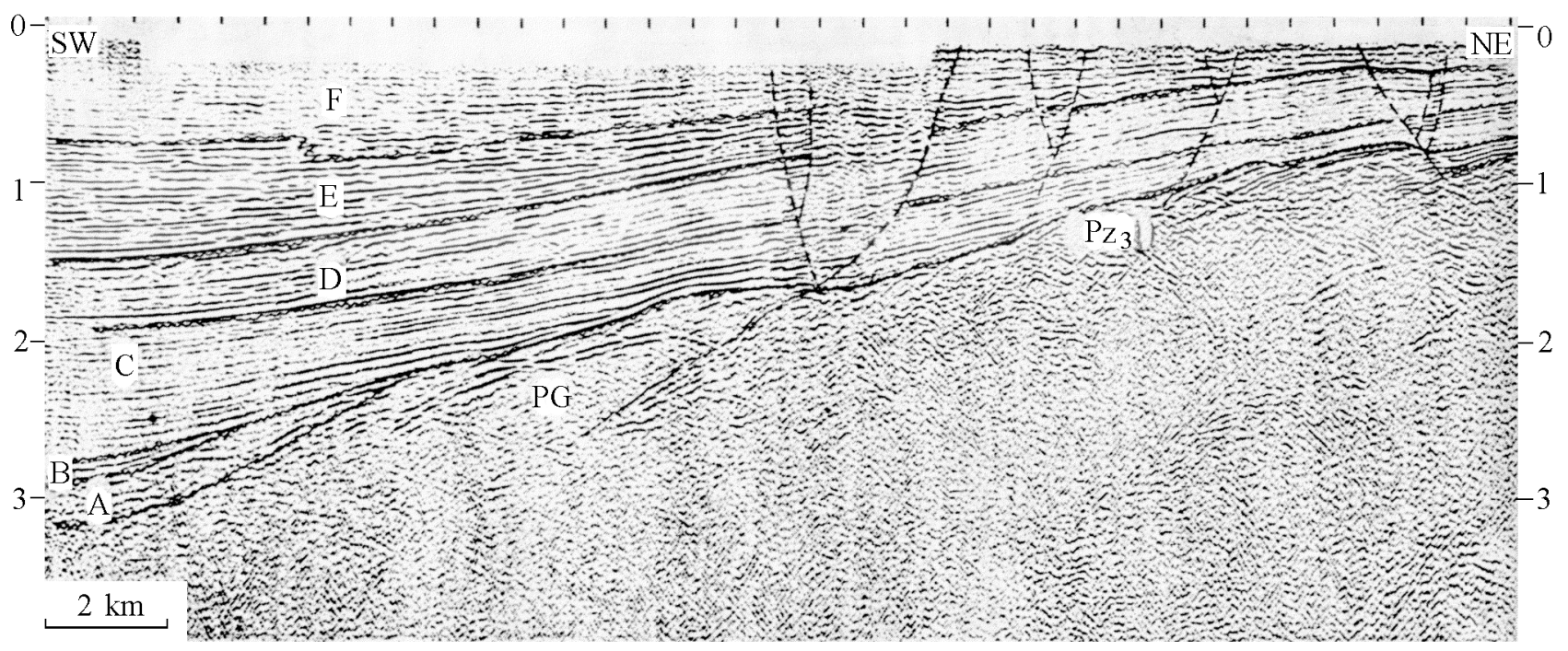

Figure 12. Seismic section illustrating the variation of the thickness and facies $(A, B, \ldots F)$ of the Pannonian sediments in the direction from the subsidence region to synsedimentary uplift area [Pogacsas, 1984a]. Thickness in seconds.

the framework of the geosyncline concept, subdivided into two stages: the early orogenic stage (Late Eocene-Middle Miocene) [Milanovskii and Koronovskii, 1973] is represented by rocks of the calc-alkaline series and the second stage (since the Pannonian Age up to present) corresponds to the final magmatism of Stille [1964] associated with eruptions of alkalic basalts. Importantly, the development of peripheral basins inside the Carpathian loop during an interval of 1610.5 Ma coincided in time with the most intense phase of the calc-alkaline magmatism.

For the purposes of this work, of interest is the analysis of the Late Miocene-Quaternary volcanism, when the calcalkaline volcanism drastically changed to the alkali-basaltic type at the very beginning of the Pannonian Age throughout the vast CBR territory; this was an event of paramount importance for the understanding of the neotectonic geodynamics. Its significance was noted by Stille [1964], who attributed it to the final type of volcanism accomplishing the geosynclinal development.

What does the final volcanism mean? Stille [1964] introduced this term in order to describe the magmatic activity starting after folding processes had stopped in a geosynclinal region. As was emphasized by G. Stille, the most important features of the final volcanism are (1) association with faulting tectonics (Blockgebirge), (2) general consolidation and cratonization of the crust and (3) a change in deep conditions of magma generation. Moreover, G. Stille introduced the special term "Rhein-type orogenesis" defining the Rhein graben as a tectonotype. General patterns of the final volcanism noted by G. Stille are still valid but geodynamic implications of this type of volcanism have been unclear until recently.

The final volcanism was most widespread in the Pannon- ian basin, although it was an order of magnitude smaller in volume than volcanics of the early orogenic stage. Alkali basalts outcrop in the areas of Mts. Somlo and Sag (Little Hungarian basin), Hungarian Midmountains (Bakony Mountains), vicinities of Shalgotoryan (Nograd) and Tokay Mountains [Balogh, 1983; Jugovics, 1974; Szabo et al., 1992]. Basalts have also been discovered in many drillcores from the sedimentary sequence of Pannonian deposits (Kiskunhalas, Kesel, Ruzsha, Shandorfalva and others) [Molasse ..., 1981; Jambor, 1989].

The Kec-2 hole penetrated $350 \mathrm{~m}$ of basalts and did not leave them at a depth of $1350 \mathrm{~m}$; basalts occur here directly under Lower Pannonian (sensu stricto) deposits. The Kec-1 hole encountered basalts at a 250-m depth, also under Lower Pannonian deposits; basalts are traceable here down to a depth of $1250 \mathrm{~m}$. A similar situation is observed in the Kec-4 hole, where the thickness of basalts overlying Miocene deposits is $350 \mathrm{~m}$ [Molasse ..., 1981].

These drilling data call for a revision of old ideas concerning the occurrence of basalt volcanism in the Pannonian basin that are based solely on the known descriptions of surface lavas. However, even more important is the fact that the drillcore data yield additional constraints on the stratigraphic position of basalts previously considered not older than the Pliocene.

According to biostratigraphic evidence and K-Ar and paleomagnetic datings, the basalts of the Pannonian basin range in age from the early Pannonian to Late Pleistocene. Age determinations yielded 1.4-2.8 Ma for the Nograd basalts, 2.7-5.0 Ma for basalts from the Balaton area and Little Hungarian Lowland, and 8.1-10.4 Ma for basalts from boreholes in the Kishkunhalash, Shandofalva, Ruzsha and Kesel areas [Balogh, 1983]. 


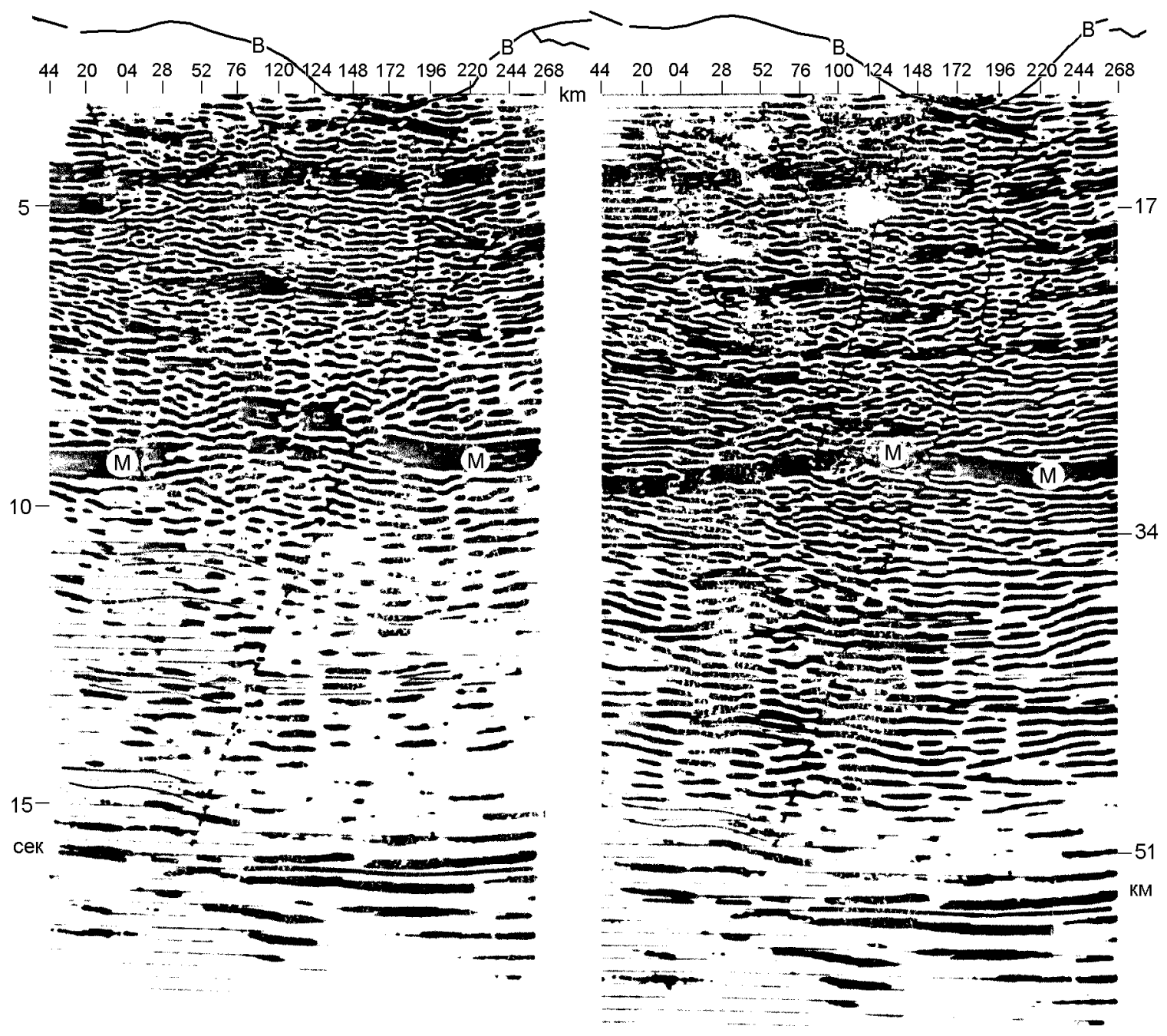

Figure 13. Seismic section for the eastern part of the Pannonian Basin [Posgay, 1989]. B - basement, $\mathrm{M}$ - Moho boundary.

Thus, the calc-alkaline to alkali-basaltic transition of the Late Eocene-Miocene volcanism in the Carpathian region took place at the very beginning of the Pannonian Age at the origination time of inner basins. It is important to note that these basalts typically contain inclusions of ultrabasic rocks.

Alkali-basaltic volcanism of the Pliocene (Dacian, Levantinian and upper Pannonian) was also widespread in the Gratz area of the Eastern Alps and in other areas near the Vienna basin [Huller, 1974; Lippolt, 1982; Machel, 1974; Poultidis, 1981]. New K-Ar datings of basalts from Burgeland and Stiria areas yielded ages ranging from 10.5 to $3.8 \mathrm{Ma}$ [Grachev, 2003 (in press)]. Evidence for basic volcanism in the Western Carpathians is found northwest and southeast of the town of Lucenec, where a few tens of outcrops of Pliocene-Quaternary basalts are known (lava flows, dikes and cinder cones). This area is an immediate northward continuation of the Nograd occurrence area of alkali basaltoids and much resembles it as regards the composition of the volcanics themselves and their ultrabasic xenoliths. Young basalts are also known in the Pershan Mountains.

North of the Carpathian arc within the Czechia-Silesia region, basic volcanism (alkalic and peralkaline lavas dominated by basalts and basanites and containing ultrabasic xenoliths) manifested itself in several places that form a zone extending for more than $500 \mathrm{~km}$ and bounding the Bohemian Massif to the northwest and northeast (Heb, Dupov Mountains and Zhitava-Luban, associated with the RudavOharetz fault zone; and Lagnitsa-Yarov, Stshelin-Zembitse and Opole, associated with the Odra River fault zone). In the Czechian Massif, volcanism started to develop in the Oligocene-Early Miocene, stopped for $8 \mathrm{Myr}$ and entered a new activity phase spanning the Late Miocene-Quaternary; importantly, the onset of the latter coincided in time with the transition from the calc-alkalic to alkali-basaltic types of volcanism within the Carpathian region. 
Table 2. Average chemical composition and normative characteristics (\%) of Pliocene-Quaternary rocks of the Pannonian Basin [Grachev, 2000]

\begin{tabular}{|c|c|c|c|c|c|c|c|c|c|c|c|c|}
\hline & 1 & 2 & 3 & 4 & 5 & 6 & 7 & 8 & 9 & 10 & 11 & 12 \\
\hline $\mathrm{SiO}_{2}$ & 45.71 & 47.08 & 46.36 & 46.29 & 47.44 & 45.63 & 47.61 & 47.89 & 47.76 & 51.43 & 51.93 & 50.27 \\
\hline $\mathrm{TiO}_{2}$ & 2.30 & 2.25 & 1.87 & 1.97 & 1.86 & 2.21 & 1.62 & 1.14 & 1.15 & 0.60 & 0.83 & 0.69 \\
\hline $\mathrm{Al}_{2} \mathrm{O}_{3}$ & 15.45 & 14.93 & 17.59 & 15.97 & 16.23 & 15.96 & 16.26 & 17.11 & 17.08 & 18.50 & 18.89 & 19.83 \\
\hline $\mathrm{FeO}^{*}$ & 9.70 & 9.48 & 9.44 & 10.09 & 9.80 & 9.94 & 8.62 & 7.35 & 7.35 & 9.09 & 9.47 & 9.11 \\
\hline $\mathrm{MgO}$ & 9.18 & 7.06 & 6.12 & 7.51 & 7.87 & 7.80 & 10.53 & 8.52 & 8.64 & 5.35 & 4.84 & 4.22 \\
\hline $\mathrm{CaO}$ & 9.16 & 8.56 & 9.69 & 8.93 & 8.75 & 9.06 & 10.16 & 9.32 & 9.44 & 10.01 & 7.99 & 10.20 \\
\hline $\mathrm{Na}_{2} \mathrm{O}$ & 3.64 & 3.55 & 4.17 & 3.52 & 3.21 & 2.65 & 3.15 & 2.57 & 2.47 & 1.86 & 2.58 & 2.17 \\
\hline $\mathrm{K}_{2} \mathrm{O}$ & 1.59 & 1.89 & 2.15 & 1.91 & 1.81 & 2.17 & 1.38 & 1.37 & 1.30 & 0.90 & 1.20 & 1.00 \\
\hline $\mathrm{Q}$ & - & - & - & - & - & - & - & - & - & 6.77 & 6.21 & 4.67 \\
\hline Or & 9.39 & 11.17 & 12.70 & 11.28 & 10.69 & 12.82 & 8.14 & 8.05 & 8.15 & 5.32 & 7.09 & 5.91 \\
\hline $\mathrm{Ab}$ & 18.03 & 23.73 & 14.08 & 19.46 & 23.84 & 16.14 & 16.27 & 21.78 & 20.72 & 15.73 & 21.82 & 18.35 \\
\hline An & 21.13 & 19.23 & 22.94 & 22.14 & 24.54 & 25.25 & 26.80 & 31.09 & 31.16 & 39.47 & 36.42 & 41.42 \\
\hline $\mathrm{Ne}$ & 6.91 & 3.41 & 11.48 & 5.59 & 1.79 & 3.40 & 5.62 & - & - & - & - & - \\
\hline Di & 19.10 & 18.51 & 20.07 & 17.60 & 14.94 & 15.83 & 18.81 & 12.05 & 13.91 & 8.25 & 2.59 & 7.48 \\
\hline Hy & - & - & - & - & - & - & - & 6.55 & 2.88 & 16.32 & 16.29 & 13.46 \\
\hline $\mathrm{Ol}$ & 11.32 & 9.45 & 5.47 & 10.26 & 11.44 & 13.93 & 17.70 & 9.88 & 12.65 & - & - & - \\
\hline $\mathrm{Hm}$ & 4.37 & 4.27 & 3.55 & 3.74 & 3.53 & 4.20 & 3.10 & 2.16 & 2.23 & 1.14 & 1.58 & 1.31 \\
\hline Mt & 6.48 & 5.03 & 5.35 & 6.12 & 6.19 & 3.86 & 3.09 & 3.67 & 3.68 & 4.73 & 5.73 & 4.89 \\
\hline $\mathrm{N}$ & 13 & 45 & 46 & 56 & 41 & 40 & 4 & 7 & 8 & - & - & - \\
\hline
\end{tabular}

Note: 1 - basalts, including xenoliths of spinel lherzolites; 2 - West Danube basin; 3 - Salgotarjan area; 4-6 - Bakony Mountains; 7-9 Northeastern Carpathian: 7 - Kaliman-Hargita Mountains, 8 - Tokai Mountains, 9 - Sarospatak drillhole 10; 10-12 - Transcarpathian region. $\mathrm{N}$ - number of analyses.

Alkalic basalts of a similar composition containing ultrabasic xenoliths have long been known and are presently well studied within Poland [Alibert et al., 1987; Blusztajn and Hart, 1989]. In their isotope-geochemical systematics, they are similar to basalts of the Pannonian basin [Grachev, 2003 (in press)].

Thus, the Late Miocene-Quaternary basic volcanism in the vast territory of the Pannonian basin and adjacent areas had no relation to the pre-neotectonic structural pattern. Its characteristic feature is the general petrographic composition and the presence of xenoliths in the spinel lherzolite facies [Grachev, 2000; Grachev et al., 1987b].

The only exception in the entire Carpathian region is the Eastern Carpathians and the Transcarpathian basin, where young volcanics classified as the Gutinian and Buzhorian formations (analogs of Pannonian 10-11-Ma deposits) are represented by basalts, andesite basalts and andesites forming a differentiated series [Geochemistry ..., 1976; Maleev, 1964]. These rocks constitute small nappes, cinder cones and subvolcanic structures within the Buzhora and Lesser Sinyak mountains and Vygorlat-Gutin Ridge. The origin of this Eastern Carpathians series can be elucidated from the discussion of the volcanics petrochemistry and neotectonic geodynamics.

Petrochemical systematics of alkali basalts of the Carpathian basin and surrounding areas has been established using the petrochemical bank of world basalts (more than 60000 analyses) created by the author and the appropriate technique [Grachev, 1987a] enabling the determination of the geodynamic position for given sets of analyses.
Along with published data from the Carpathian region, our data provided a sample of about 300 chemical analyses. Tables 2, 3 and 4 present average compositions of neotectonic volcanics in the Carpathian region and adjacent areas.

Data of Table 2 suggest that all volcanics belong to two main petrochemical types: (1) alkalic type including undifferentiated alkalic olivine basalts and basanites (columns 1-6 in Table 2) with normative nepheline that were produced by fissure eruptions and (2) calc-alkaline type embracing high-alumina low-Ti basalt-andesite-dacites with typically present normative quartz and corundum that resulted from activity of central-type volcanoes (columns 7-12 in Table 2).

Many petrochemical features are common to volcanic manifestations in the Czechian- Silesian region and adjacent areas of Thuringia, Saxony and the Vienna basin (Tables 3 ). Along with alkali basalts and basanites, alkalic lavas strongly depleted in silica occur here (limburgites, melilites, nephelinites, olivine and olivine-free foidites, tephrites and phonolites (Lausitz)). These rocks are particularly typical of the Dupov Mountains, Saxony and Thuringia.

Specific features of volcanics in this region are best expressed in CIPW compositions characterized by the appearance of such minerals as leucite, larnite and kalsilite; noteworthy are very low concentrations of albite (no more than $10 \%)$.

The AFM diagram (Figure 14) clearly shows that the field of Czechia-Silesia volcanics compositions is shifted closer to the $\mathrm{FeO}^{*}-\mathrm{MgO}$ line compared to the field of Pannonian basin basalts, although the differentiation trend is basically the same for both types of rocks: a decrease in the concentration 
Table 3. Average chemical composition and normative characteristics (\%) of Pliocene-Quaternary rocks of the Bohemian Massif, Turingen, Saxony and the Vienna Basin [Grachev, 2000]

\begin{tabular}{|c|c|c|c|c|c|c|c|c|c|c|}
\hline & 1 & 2 & 3 & 4 & 5 & 6 & 7 & 8 & 9 & 10 \\
\hline $\mathrm{SiO}_{2}$ & 40.38 & 42.71 & 42.61 & 41.79 & 41.72 & 41.58 & 45.41 & 37.47 & 40.72 & 47.89 \\
\hline $\mathrm{TiO}_{2}$ & 3.40 & 2.80 & 3.06 & 2.81 & 3.15 & 3.24 & 1.95 & 4.66 & 4.16 & 1.14 \\
\hline $\mathrm{Al}_{2} \mathrm{O}_{3}$ & 12.57 & 13.46 & 13.11 & 12.20 & 13.01 & 13.24 & 14.39 & 10.73 & 12.35 & 17.11 \\
\hline $\mathrm{FeO}^{*}$ & 12.55 & 12.60 & 11.23 & 11.80 & 11.10 & 12.02 & 9.70 & 15.19 & 12.81 & 7.35 \\
\hline $\mathrm{MgO}$ & 10.77 & 9.97 & 9.76 & 13.30 & 11.11 & 9.90 & 8.28 & 6.95 & 6.58 & 8.52 \\
\hline $\mathrm{CaO}$ & 12.56 & 11.80 & 11.56 & 10.85 & 12.03 & 12.18 & 9.44 & 15.75 & 13.46 & 9.32 \\
\hline $\mathrm{Na}_{2} \mathrm{O}$ & 3.31 & 3.01 & 3.13 & 2.37 & 2.90 & 3.21 & 4.14 & 2.69 & 2.83 & 2.57 \\
\hline $\mathrm{K}_{2} \mathrm{O}$ & 1.09 & 1.30 & 1.28 & 1.01 & 1.07 & 1.32 & 2.18 & 1.07 & 1.27 & 1.37 \\
\hline Or & - & 7.68 & 7.56 & 5.97 & 6.32 & 7.80 & 12.88 & - & 7.50 & 8.05 \\
\hline $\mathrm{Ab}$ & - & 3.93 & 6.68 & 5.70 & 3.26 & 1.07 & 7.90 & - & 3.69 & 21.78 \\
\hline An & 16.22 & 19.38 & 17.94 & 19.67 & 19.32 & 17.82 & 14.25 & 14.83 & 17.24 & 31.09 \\
\hline $\mathrm{Ne}$ & 15.17 & 11.67 & 10.73 & 7.77 & 11.52 & 14.14 & 14.69 & 13.06 & 10.97 & - \\
\hline $\mathrm{Lc}$ & 5.05 & - & - & - & - & - & - & 4.09 & - & \\
\hline Cs & - & - & - & - & - & - & - & 2.28 & - & \\
\hline Di & 36.12 & 31.27 & 31.11 & 27.05 & 31.82 & 33.71 & 26.44 & 43.58 & 38.83 & 12.05 \\
\hline $\mathrm{Ol}$ & 11.15 & 12.17 & 9.30 & 18.65 & 11.50 & 9.13 & 13.85 & - & - & 9.88 \\
\hline $\mathrm{Ilm}$ & 5.77 & 5.32 & 5.81 & 5.34 & 5.98 & 6.15 & 3.70 & 9.37 & 7.90 & 2.16 \\
\hline $\mathrm{Mt}$ & 6.58 & 6.23 & 6.60 & 6.07 & 6.35 & 6.87 & 1.81 & 11.20 & 8.20 & 3.67 \\
\hline $\mathrm{N}$ & 9 & 25 & 15 & 10 & 25 & 125 & 1 & 8 & 33 & 7 \\
\hline
\end{tabular}

Note: 1-3 - Northwestern Bohemian Massif; 4 - basanites, containing xenoliths of spinel lherzolites; 5-7 - Saxony and Turingen; 8-9 - Dupovsky Mountains, Czech Forest; 10 - Vienna Basin, Stiria.

of refractory components and enrichment in alkalis and silica (the Bowen trend), which is typical of volcanics in rift zones [Grachev, 1987a].

The geodynamic position of volcanics in the Carpathian

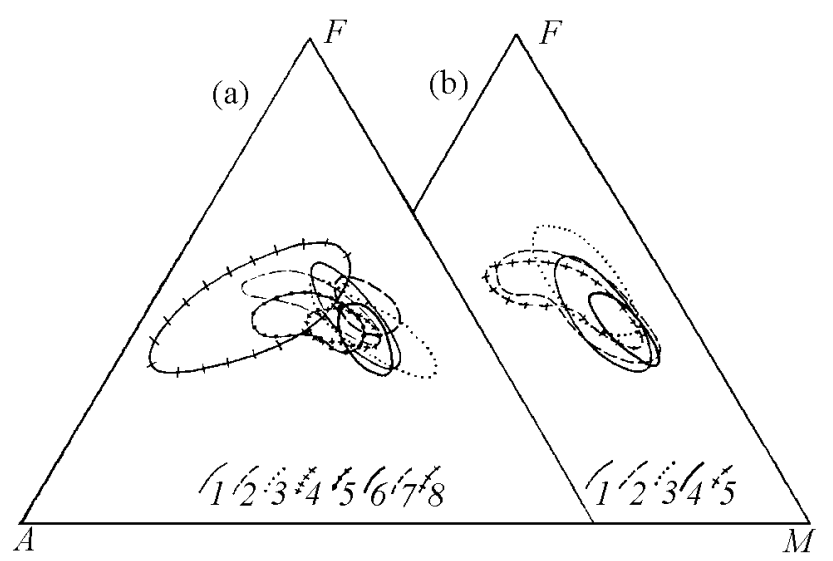

Figure 14. AFM diagram from basalts of the Carpathian region and adjacent [Grachev et al., 1987a]. (a) Carpathian region: (1) southern Bakony Mountains; (2) Little Hungarian basin; (3) Great Hungarian basin; (4) northeastern Bakony Mountains; (5) Nograd (Shalgotoryan and Luchenets); (6) basalts containing spinel lherzolite xenoliths; (7) northern Bulgaria; (8) differentiated series of the Eastern Carpathians. (b) Czechian-Silesian arc: (1) Thuringia and Saxony (limburgites, melilites and basalts); (2) Saxony; (3) Czechian Massif; (4) basalts containing spinel lherzolite xenoliths; (5) Silesia. region was determined on the basis of the generalized matrix of basalt compositions of all known geodynamic settings using the method of principal components [Grachev, 1987a]. Figure 15, in which data points of average compositions of the study regions are plotted in the plane with factor axes 1 and 2, clearly indicates that the basalt compositions of the Pannonian basin and Czechia-Silesia region lie in the basalt field of typical continental rifts, whereas Eastern Carpathians basalts fall into the composition field of island arcs, active continental margins and orogenic areas developing under the lithosphere compression conditions.

The differentiated series of the Eastern Carpathians and Transcarpathian region formed at the time when the alkalibasaltic volcanism was active in the rest of the CarpathianBalkan region, which makes the problem of geodynamic position of the series basically important. The presence of normative corundum in andsite-basalts and andesites markedly distinguish these rocks from typical andesites forming at convergent plate boundaries [Gill, 1981].

The AFM field of the differentiated series of Eastern Carpathians and Transcarpathian region (Figure 16) lies mostly below the boundary separating the tholeiitic and calc-alkaline series [Irvine and Baragar, 1971], and trend axis of the hypersthene series coincides with the axis of the ellipse formed by data points of the volcanics considered (after Kuno [1968], the hypersthene series is an analogue of the calc-alkaline series).

The position of basalt compositions of the Eastern Carpathians differentiated series in the factor diagram (Figure 15) indicates that they fall all into the area of basalts forming under lithosphere compression conditions, i.e. at convergent plate boundaries. 
Table 4. Average chemical composition and normative characteristics (\%) of Pliocene-Quaternary rocks of the Bar Village Region (drillhole Bar6), Pannonian Basin, [Grachev, 2000]

\begin{tabular}{|c|c|c|c|c|c|c|c|c|c|c|c|c|c|c|}
\hline & $\begin{array}{r}1 \\
33.0\end{array}$ & $\begin{array}{r}2 \\
38.5\end{array}$ & $\begin{array}{r}3 \\
47.9\end{array}$ & $\begin{array}{r}4 \\
51.0\end{array}$ & $\begin{array}{r}5 \\
52.8\end{array}$ & $\begin{array}{r}6 \\
55.3\end{array}$ & $\begin{array}{r}7 \\
57.8\end{array}$ & $\begin{array}{r}8 \\
60.6\end{array}$ & $\begin{array}{r}9 \\
61.6\end{array}$ & $\begin{array}{r}10 \\
64.6\end{array}$ & $\begin{array}{r}11 \\
74.1\end{array}$ & $\begin{array}{r}12 \\
77.1\end{array}$ & $\begin{array}{r}13 \\
78.8\end{array}$ & Average \\
\hline $\mathrm{SiO}_{2}$ & 50.76 & 50.32 & 50.47 & 49.80 & 48.22 & 49.76 & 49.46 & 49.38 & 49.40 & 49.16 & 49.40 & 50.14 & 50.54 & 49.75 \\
\hline $\mathrm{TiO}_{2}$ & 2.68 & 2.68 & 2.72 & 2.68 & 3.04 & 2.88 & 2.68 & 2.56 & 2.40 & 2.68 & 2.56 & 2.40 & 2.28 & 2.63 \\
\hline $\mathrm{Al}_{2} \mathrm{O}_{3}$ & 13.28 & 13.79 & 13.04 & 13.59 & 13.46 & 13.66 & 13.23 & 13.95 & 13.21 & 13.01 & 13.07 & 13.57 & 14.02 & 13.45 \\
\hline $\mathrm{FeO}^{*}$ & 6.68 & 7.26 & 7.25 & 7.62 & 7.61 & 7.25 & 7.85 & 7.72 & 7.61 & 7.73 & 7.61 & 7.61 & 7.48 & 7.81 \\
\hline $\mathrm{MnO}$ & 0.12 & 0.12 & 0.12 & 0.13 & 0.13 & 0.12 & 0.12 & 0.12 & 0.13 & 0.13 & 0.12 & 0.13 & 0.12 & 0.12 \\
\hline $\mathrm{MgO}$ & 7.29 & 7.29 & 8.46 & 7.29 & 8.67 & 8.03 & 7.83 & 7.93 & 8.89 & 8.99 & 8.99 & 7.72 & 7.62 & 8.08 \\
\hline $\mathrm{CaO}$ & 5.89 & 5.98 & 5.84 & 6.73 & 6.18 & 6.13 & 6.77 & 6.39 & 6.63 & 6.23 & 6.43 & 7.06 & 6.48 & 6.36 \\
\hline $\mathrm{Na}_{2} \mathrm{O}$ & 1.84 & 2.27 & 2.10 & 2.44 & 2.93 & 2.90 & 2.87 & 2.95 & 2.59 & 2.97 & 2.00 & 2.83 & 2.68 & 2.57 \\
\hline $\mathrm{K}_{2} \mathrm{O}$ & 7.96 & 6.70 & 6.92 & 6.78 & 6.51 & 6.39 & 6.70 & 6.32 & 6.70 & 6.43 & 5.48 & 5.99 & 5.84 & 6.52 \\
\hline $\mathrm{P}_{2} \mathrm{O}_{5}$ & 1.15 & 1.08 & 1.02 & 1.01 & 1.06 & 1.06 & 1.07 & 1.09 & 1.01 & 1.01 & 0.89 & 0.95 & 0.92 & 1.02 \\
\hline Or & 47.04 & 9.59 & 40.89 & 40.07 & 38.47 & 37.76 & 39.59 & 37.35 & 39.59 & 38.00 & 32.38 & 35.40 & 34.51 & 38.51 \\
\hline $\mathrm{Ab}$ & 8.24 & 14.59 & 12.57 & 9.48 & 6.55 & 10.85 & 6.26 & 8.91 & 4.22 & 6.04 & 16.27 & 10.23 & 14.66 & 10.28 \\
\hline An & 4.47 & 7.65 & 5.72 & 6.11 & 4.35 & 5.38 & 3.43 & 6.16 & 4.63 & 3.18 & 10.50 & 6.63 & 8.98 & 5.94 \\
\hline $\mathrm{Ne}$ & 3.97 & 2.50 & 2.82 & 6.05 & 9.89 & 7.42 & 9.76 & 8.70 & 9.59 & 10.34 & 0.35 & 7.43 & 4.34 & 6.20 \\
\hline $\mathrm{Di}$ & 13.42 & 11.65 & 12.91 & 16.10 & 15.09 & 14.26 & 18.26 & 14.60 & 17.23 & 16.79 & 12.32 & 17.71 & 13.69 & 14.88 \\
\hline $\mathrm{Ol}$ & 8.37 & 8.94 & 10.57 & 7.50 & 10.23 & 11.08 & 9.47 & 11.80 & 13.59 & 13.74 & 14.29 & 11.59 & 12.55 & 10.53 \\
\hline $\mathrm{Hm}$ & 0.41 & 2.22 & 1.92 & 4.57 & 2.54 & - & - & - & - & - & - & - & - & - \\
\hline Mt & 4.32 & 3.20 & 3.43 & 1.33 & 2.93 & 3.77 & 4.54 & 3.77 & 3.03 & 3.03 & 3.77 & 2.84 & 3.00 & 4.60 \\
\hline Il & 5.09 & 5.09 & 5.17 & 5.09 & 5.77 & 5.47 & 5.09 & 4.86 & 4.56 & 5.09 & 4.86 & 4.56 & 2.43 & 5.00 \\
\hline Ap & 2.72 & 2.56 & 2.42 & 2.39 & 2.51 & 2.51 & 2.53 & 2.58 & 2.39 & 2.39 & 2.11 & 2.25 & 2.77 & 2.43 \\
\hline
\end{tabular}

Note: Cipher means the depth of sampling.

Thus, geochemical individuality of the Eastern Carpathians calc-alkaline series is undoubted. Does this mean that subduction was still active at that time? From the stand-

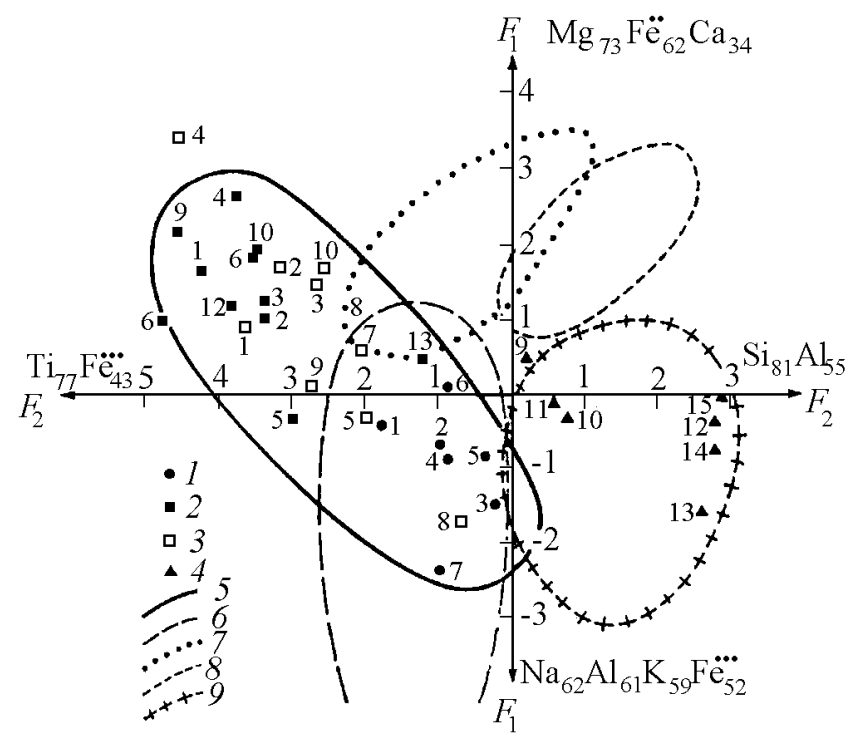

Figure 15. Data points showing average chemical compositions for the Carpathian region and Czechian-Silesian arc in plane axes of factors 1 and 2 (see explanations in text) [Grachev et al., 1987a]: (1, 4) see Table 2; (2) see Table 3 ; (3) see Table 4; (numbers in the figure indicate the columns in the tables); (5-9) basalt fields of (5) continental rifts, (6) oceanic islands, (7) oceanic hotspots, (8) midocean ridges and $(9)$ island arcs, active continental margins and collisional orogens [Grachev et al., 1987b]. point of plate tectonics, the presence of the calc-alkalic series is invariably associated with subduction, which is a serious mistake usually involved in paleotectonic reconstructions [Gill, 1981].

Compared to other parts of the Carpathian region, of particular neotectonic importance is the Pannonian basin whose geodynamic origin, as noted above, is interpreted ambiguously. Since volcanism is crucial for the solution of this problem, we present new geochemical data obtained from

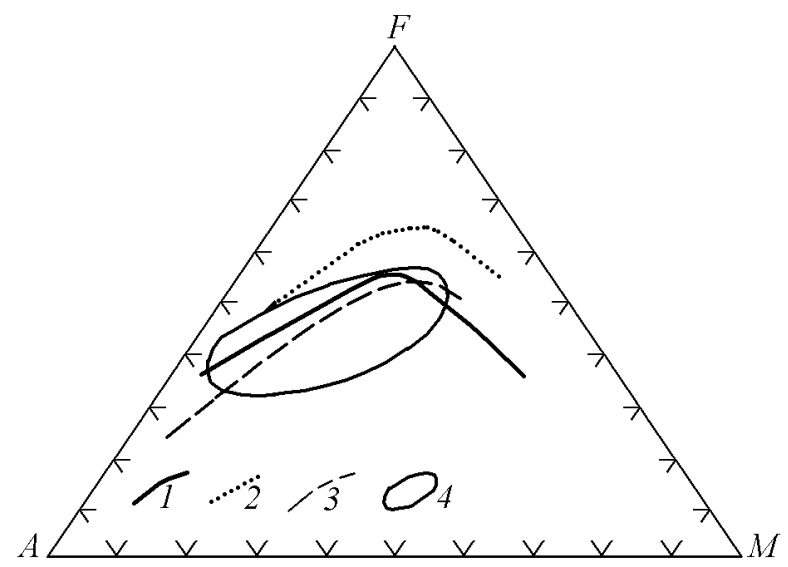

Figure 16. AFM diagram of differentiated series of Eastern Carpathian volcanics (Late Miocene-Pleistocene) [Grachev et al., 1987b]: (1) boundary between the tholeiitic and calcalkalic series [Irvine and Baragar, 1971]; (2, 3) differentiation trends of the pigeonite and hypersthene series [Kuno, 1968]; (4) composition field of the Eastern Carpathian differentiated series. 
Table 5. Average chemical composition and normative characteristics (\%) of Pliocene basalts of the Bulgaria [Grachev, 2000]

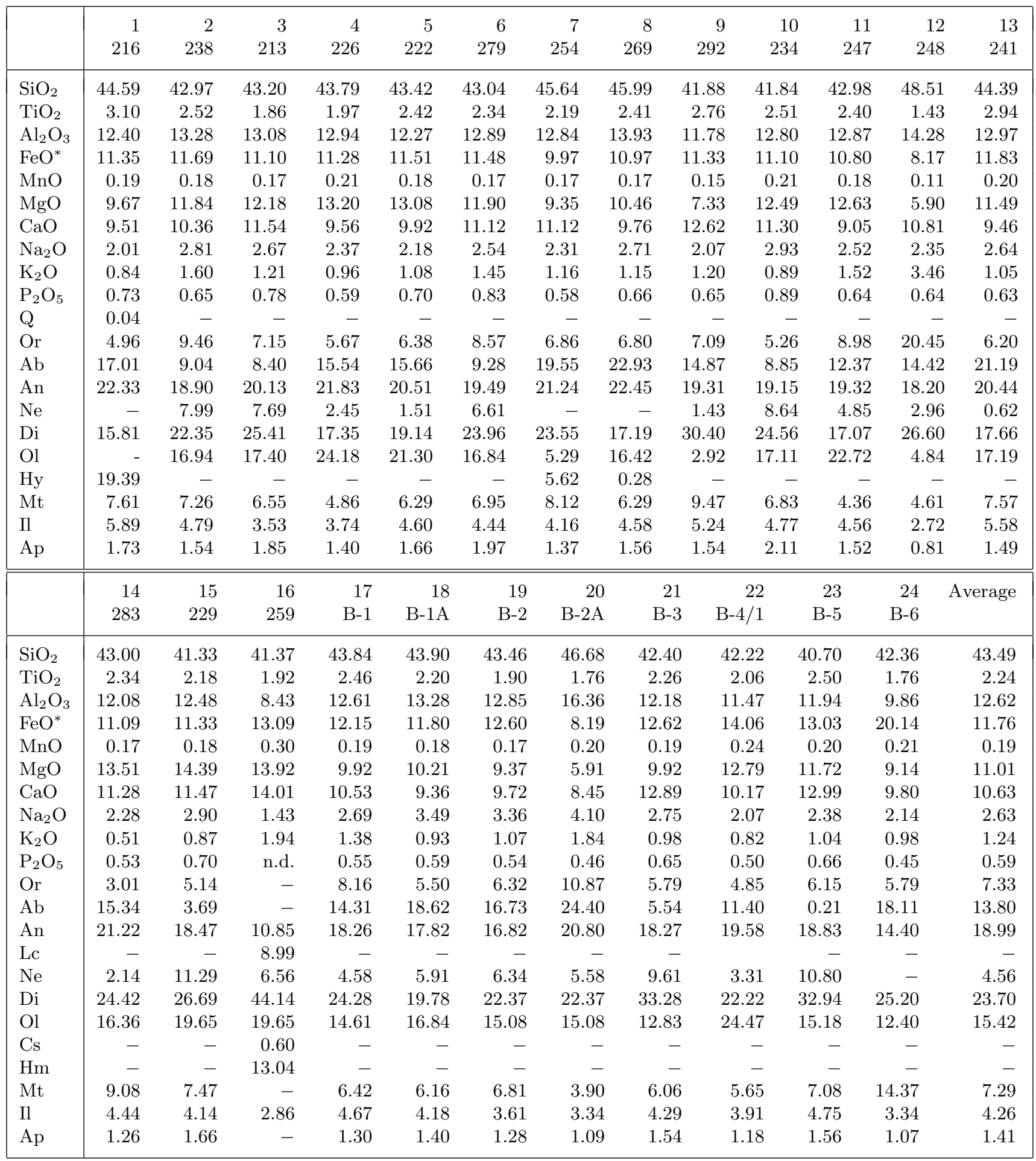

Note: 1 - between Suhindol and Verbovka villages, 2 - Orta Tepe Mountain between Verbovka and Butovo villages, 3 - Suhindol, 4 - Verbovka village, Kosmatiza, 5 - Butovo village, Kavlaka Mountain, 6 - Chervena village, quarry, 7 - Butovo village, Daicheva Mogila, 8 - Slomer village, 9 - Kunte Mogila, between Ovcha Mogila and Chervena villages, 10 - Kitkat village, 11, 12 - Chatkal Tepe Mountain, 13 - Butovo village, 14 - Dragomirovo village, 15, 16 - Kitkat village, 17, 18, 19, 20 - Vonische Vody, 21 - Varana village, 22 - Verbovka village, 23 - Orta Tepe Mountain between Verbovka and Butovo villages, 24 - Kara Tepe Mountain, the same place. 
recently accomplished studies [Grachev, 2003 (in press)].

Taking into account the data of Tables 2 and 4 , we can distinguish two groups of volcanics. The first group includes alkali basalts, hawaiites and basanites which are the most widespread types of volcanics in the Pannonian basin; the second group includes basalts from drillcores of a hole near the Bar village (southern Pannonian basin) [Szederkenyi, 1980]; we sampled the Bar-6 holes (in a depth interval of 33.0-78.8 m) and made 13 comprehensive chemical analyses (Table 4). The basalts samples range in age from 0.17 to 2.17 Ma [Balogh, 1983].

Actually, the Bar basalts basically differ from all other alkali basalts of the Pannonian basin in a very high $\mathrm{K}_{2} \mathrm{O}$ concentration (with a maximum of $7.96 \%$ at a 33.0-m depth) and in marked predominance of $\mathrm{K}_{2} \mathrm{O}$ over $\mathrm{Na}_{2} \mathrm{O}$ (on average, $\mathrm{K}_{2} \mathrm{O} / \mathrm{Na}_{2} \mathrm{O}=2.54$ ). The Bar basalts can be classified as potassium trachybasalts according to Irvine and Baragar [1971] and as leucite basanites according to Cox et al. [1982].

Many petrologists believe that a high $\mathrm{K}$ concentration can be accounted for by either mantle metasomatism or a specific mantle composition with a high $\mathrm{K}$ concentration at depths of more than $70 \mathrm{~km}$ (which is more probable, by analogy with the Western segment of the East African rift system). The problem on the genesis of the Bar basalts remains unsettled until the accomplishment of isotopic studies.

To sum up, we note that a sharp change in petrochemical types of volcanic activity at the Sarmatian/Pannonian boundary within the Pannonian basin and in the rest of the CBR is basically important for elucidating the origin of deepseated processes. As shown above, a complex of characteristic features indicates that alkaline and peralkaline CBR rocks are indistinguishable from volcanics of typical continental rifts.

A similar association of Quaternary alkali basalts was found in the Hartiga Mountains (right-hand tributaries of the Olt River, Eastern Carpathians) [Maldarescu et al., 1983], which continues northward the young volcanism zone extending (along $25^{\circ} \mathrm{E}$ ) through the southern part of the Moesian plate [Redulescu, 1979], Midmountains, Stara Planina and Pre-Balkan region and crossing all structures of the early orogenic stage (Table 5). Numerous outcrops of young basalts are known within the Rhodope and SerbianMacedonian massifs [Machel, 1974].

The above conclusion necessarily suggests that since 11.010.5 Ma the development of volcanism in the most territory of CBR occurred under conditions of lithosphere extension. The idea that volcanism of the Pannonian basin has no relation to its development [Szabo et al., 1992] proves invalid. This statement was supported by Embey-Isztin et al. [2001], who rightly pointed out that ideas on the compression state of the Pannonian basin lithosphere [Bada et al., 1999] are invalid. The calc-alkalic volcanism in the Eastern Carpathians develops under conditions of lithosphere compression inherited from the early orogenic stage.

Finally, we draw attention of the reader to the following, basically new conclusion: the identification of the rift origin of the "final" volcanism implies that areas of its manifestations are involved in the process of the lithosphere destruction at its various stages (prerift stage in the Czechian Massif and rift stage in the Pannonian basin).

\section{Geodynamic Zoning of the Pannonian Basin}

The construction of geodynamic maps has been widely developed recently. As a rule, they reflect kinematic reconstructions of authors imaging the movements of individual lithospheric blocks and incorporating data on earthquake distributions and focal mechanisms. A subjective factor plays a pronounced role in such reconstructions. This paper proposes an approach to the construction of geodynamic regionalization maps based on quantification of parameters of the geological-geophysical medium.

As a method of studying recent geodynamics and neotectonics, the geodynamic zoning was developed relatively recently when processing of large datasets became possible by using methods of mathematical analysis and computer technologies. The effectiveness of such data processing methods as trend, factor and cluster analyses was demonstrated previously [Grachev and Mishin, 1975; Grachev, 2000; Grachev et al., 1987a, 1987b]. It was shown that only a synthetic approach including preliminary analysis of each parameter of the geological-geophysical medium and elucidation of possible correlations between all parameters is capable of eliminating "noise" arising if either interdependent variables or a parameter that cannot be a priori specified are introduced into the analysis.

A geological-geophysical database including 22 parameters was initially created for the Pannonian basin (see list of parameters in Table 6). For this purpose, data obtained during the work on assessing the seismic hazard of the Paks NPP in 1986-1990, as well as data from literature sources, were used [Grachev et al., 1987c, 1989b]. The entire dataset was digitized on a $20^{\prime} \times 30^{\prime}$ grid.

The results of correlation analysis (Table 7) show that several parameters are highly correlated between themselves and, moreover, such parameters as vertical recent crustal movements (VRCM) are represented by five largely different datasets (five maps published in different years). This required special VRCM studies which showed that only the map of 1995 is physically significant [Grachev et al., 2001a, 2001b]. Additional data on the deep structure of the Pannonian basin obtained during these studies allowed us to include updated estimates of the Moho depth and the $P_{\mathrm{n}}$ wave velocity distribution at this boundary into the database. Note that the new data on the Moho depth [Weber, 2002] weakly correlate with the older data $(r=0.33)$ [Posgay and Szentgyorgi, 1991].

However, it is most important that curvatures of neotectonic vertical crustal movements (NVCM), rather than the commonly used modulus of NVCM amplitude gradient, were used as strain characteristics [Ekman, 1985; Grachev et al., 1988, 1989a, 1990; Lisle, 1994; Nothard et al., 1996]. Bending curvatures of the lithosphere are preferable to amplitudes and gradients of NVCM because they are invariant under the motion of a lithospheric block as a rigid whole and therefore can be related to active tectonic stresses.

Further efforts pursued more comprehensive incorporation of NVCM kinematics; for this reason, tensor characteristics the NVCM-induced bending of the surface were ana- 
Table 6. Initial geological and geophysical data

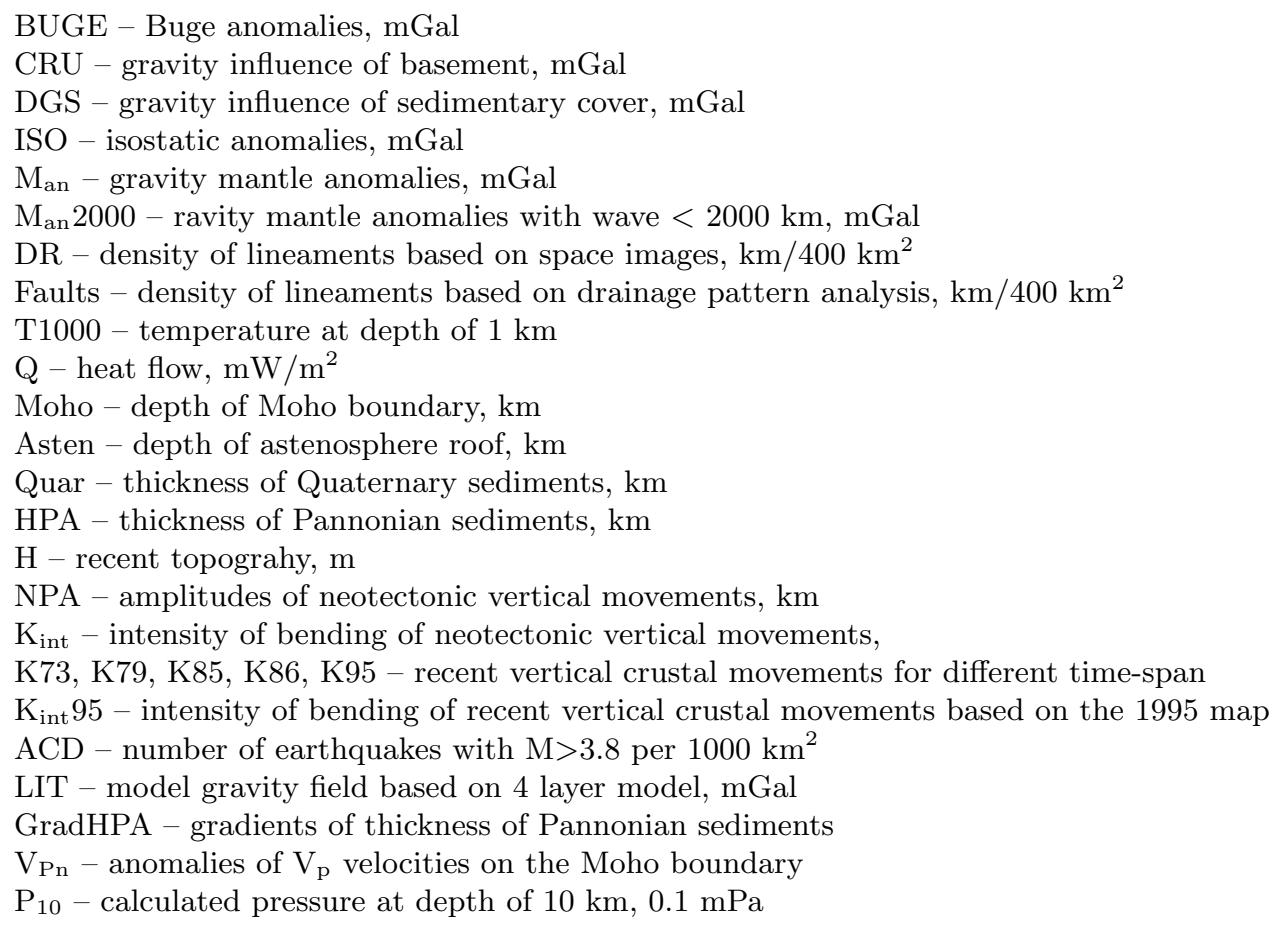

lyzed [Grachev et al., 1995a, 1995b]. In a linear approximation, eigenvalues of the curvature-torsion tensor are the principal curvatures $K_{\max }(x, y)$ and $K_{\min }(x, y)$ of the vertical movement field, i.e. the principal curvatures that should arise in an initially plane surface under the action of NVCM.

In terms of the model describing small elastic bending strains of an isotropic lithosphere, the curvature-torsion tensor is coaxial with the bending moment tensor, and the average curvature $K_{\text {av }}$ defined as $h\left(K_{\max }-K_{\min } / 2\right)$ ( $h$ is the lithosphere thickness) affects the shear strain intensity and thereby the value of the maximum tangential stress [Mukhamediev, 1992].

The most reliably determined curvature characteristic is the curvature intensity $K_{\mathrm{int}}$. As shown in [Grachev et al., $1995 \mathrm{~b}, 2001 \mathrm{~b}], K_{\mathrm{int}}=2 \gamma / h$, where $\gamma=\left(\varepsilon_{\max }-\varepsilon_{\min }\right) / 2$ is the horizontal shear strain intensity in the upper lithosphere associated with maximum tangential stresses and, apparently, with seismic activity.

\section{Comparative Analysis of Different Variants of the Pannonian Basin Geodynamic Regionalization Map}

The first maps of the Pannonian basin geodynamic regionalization were constructed in relation to the seismic hazard assessment for the Paks NPP and the analysis of recent crustal movements and seismicity [Grachev et al., 1989b].
Their construction involved methods of factor and cluster analyses of geological-geophysical characteristics. As easily seen, their results depend on the chosen parameters; namely, if a geodynamic regionalization map is constructed, the chosen parameters (indicators) should provide general constraints on the main geodynamic characteristics.

However, equally important the following consideration ensuing from properties inherent in the factor analysis: first, main factors must have a clear physical meaning and, second, the weight of the first three factors should make the major contribution to the total variability (as shows practice, more than $70 \%$ ).

The first regionalization variant is based on the use of the following parameters: DGS, $H, q$, Moho2002, Cru and $V_{\mathrm{P}}$. The correlation and factor load matrices are presented in Table 8. In this case, the first two factors make a more than $70 \%$ contribution to the total dispersion, which can be formally considered as a very good result. As is evident from factor loads of variables included in factor 1 , the present topography pattern is controlled by the Moho depth and density inhomogeneities in the basement (Figure 17). Factor 2 includes, with various signs, the heat flow and $P$ wave velocity anomalies in the upper mantle specified relative to an average velocity of $7.9 \mathrm{~km} / \mathrm{s}$, which is quite understandable, taking into account the strong heating of lithosphere under the Pannonian basin (Figure 18). Although the configuration of such anomalies [Weber, 2002] is evidently consistent with the estimated thickness of the thermal lithosphere [Bodri, 1996], noteworthy is the possible effect of the azimuthal seismic anisotropy in the mantle [Babuska et al., 
Table 7. Correlation matrix of initial data

\begin{tabular}{|c|c|c|c|c|c|c|c|c|c|c|c|}
\hline & BUGE & $\mathrm{CRU}$ & DGS & ISO & Manom & Manom2000 & DR & Razlomy & T1000 & $\mathrm{Q}$ & Moho \\
\hline BUGE & 1 & 0.283 & -0.206 & 0.131 & -0.180 & -0.218 & $3-0.090$ & -0.127 & -0.044 & -0.116 & -0.124 \\
\hline $\mathrm{CRU}$ & 0.283 & 1 & -0.898 & 0.257 & -0.186 & -0.137 & 0.232 & 0.241 & -0.098 & -0.006 & 0.035 \\
\hline DGS & -0.206 & -0.898 & 1 & -0.418 & -0.006 & -0.034 & $1-0.189$ & -0.151 & 0.114 & 0.063 & -0.011 \\
\hline ISO & 0.131 & 0.257 & -0.418 & 1 & 0.281 & 0.226 & 0.081 & 0.033 & 0.091 & -0.072 & -0.044 \\
\hline Manom & -0.180 & -0.186 & -0.006 & 0.281 & 1 & 0.966 & -0.066 & -0.163 & 0.009 & 0.138 & -0.109 \\
\hline Manom2000 & -0.218 & -0.137 & -0.034 & 0.226 & 0.966 & 1 & 0.008 & -0.093 & -0.122 & 0.031 & 0.003 \\
\hline DR & -0.090 & 0.232 & -0.189 & 0.081 & -0.066 & 0.008 & 1 & 0.744 & 0.007 & 0.025 & 0.094 \\
\hline Razlomy & -0.127 & 0.241 & -0.151 & 0.033 & -0.163 & -0.093 & 0.744 & 1 & 0.147 & 0.048 & -0.014 \\
\hline T1000 & -0.044 & -0.098 & 0.114 & 0.091 & 0.009 & -0.122 & 0.007 & 0.147 & 1 & 0.618 & -0.526 \\
\hline Q & -0.116 & -0.006 & 0.063 & -0.072 & 0.138 & 0.031 & 0.025 & 0.048 & 0.618 & 1 & -0.469 \\
\hline Moho & -0.124 & 0.035 & -0.011 & -0.044 & -0.109 & 0.003 & 0.094 & -0.014 & $=-0.526$ & -0.469 & 1 \\
\hline Asten & -0.233 & 0.251 & -0.228 & -0.216 & -0.274 & -0.277 & $7 \quad-0.031$ & -0.103 & -0.203 & 0.038 & 0.322 \\
\hline QUAR & 0.090 & -0.762 & 0.688 & -0.164 & 0.106 & -0.023 & $3-0.302$ & -0.283 & 0.157 & 0.062 & -0.255 \\
\hline HPA & 0.177 & 0.954 & -0.936 & 0.275 & -0.085 & -0.042 & 0.210 & 0.189 & -0.108 & -0.019 & 0.042 \\
\hline $\mathrm{H}$ & 0.037 & 0.465 & -0.417 & 0.086 & -0.135 & -0.036 & 0.349 & 0.312 & -0.342 & -0.161 & 0.417 \\
\hline NPA & 0.264 & 0.954 & -0.917 & 0.289 & -0.141 & -0.104 & 0.206 & 0.194 & $=-0.167$ & -0.062 & 0.117 \\
\hline $\mathrm{K}_{\mathrm{int}}$ & 0.065 & -0.073 & 0.001 & 0.072 & -0.002 & 0.004 & $1-0.052$ & -0.067 & -0.052 & -0.067 & -0.061 \\
\hline RCM95 & -0.077 & 0.461 & -0.521 & 0.187 & 0.162 & 0.309 & 0.265 & 0.272 & -0.265 & -0.222 & 0.184 \\
\hline $\mathrm{K}_{\text {int }} 95$ & 0.190 & -0.012 & -0.024 & 0.113 & -0.059 & -0.115 & -0.076 & -0.017 & -0.096 & -0.103 & 0.048 \\
\hline $\mathrm{ACD}$ & -0.088 & 0.258 & -0.241 & -0.083 & 0.010 & 0.034 & -0.021 & 0.018 & 0.013 & 0.174 & 0.070 \\
\hline LIT & 0.262 & 0.180 & -0.219 & 0.593 & -0.004 & -0.043 & $3-0.173$ & -0.093 & 0.053 & -0.045 & -0.178 \\
\hline \multirow[t]{2}{*}{$P_{10}$} & 0.183 & 0.909 & -0.828 & 0.228 & -0.200 & -0.132 & 0.292 & 0.293 & -0.206 & -0.056 & 0.177 \\
\hline & Asten & QUAR & HPA & $\mathrm{H}$ & NPA & $\mathrm{K}_{\mathrm{int}}$ & M95 & $\mathrm{K}_{\mathrm{int}} 95$ & $\mathrm{ACD}$ & LIT & $\mathrm{P}_{10}$ \\
\hline BUGE & -0.233 & 0.090 & 0.177 & 0.037 & 0.264 & 0.065 & -0.077 & 0.190 & -0.088 & 0.262 & 0.183 \\
\hline $\mathrm{CRU}$ & 0.251 & -0.762 & 0.954 & 0.465 & 0.954 & -0.073 & 0.461 & -0.012 & 0.258 & 0.180 & 0.909 \\
\hline DGS & -0.228 & 0.688 & -0.936 & -0.417 & -0.917 & 0.001 & -0.521 & -0.024 & -0.241 & -0.219 & -0.828 \\
\hline ISO & -0.216 & -0.164 & 0.275 & 0.086 & 0.289 & 0.072 & 0.187 & 0.113 & -0.083 & 0.593 & 0.228 \\
\hline Manom & -0.274 & 0.106 & -0.085 & -0.135 & -0.141 & -0.002 & 0.162 & -0.059 & 0.010 & -0.004 & -0.200 \\
\hline Manom2000 & -0.277 & -0.023 & -0.042 & -0.036 & -0.104 & 0.004 & 0.309 & -0.115 & 0.034 & -0.043 & -0.132 \\
\hline DR & -0.031 & -0.302 & 0.210 & 0.349 & 0.206 & -0.052 & 0.265 & -0.076 & -0.021 & -0.173 & 0.292 \\
\hline Razlomy & -0.103 & -0.283 & 0.189 & 0.312 & 0.194 & -0.067 & 0.272 & -0.017 & 0.018 & -0.093 & 0.293 \\
\hline T1000 & -0.203 & 0.157 & -0.108 & -0.342 & -0.167 & -0.052 & -0.265 & -0.096 & 0.013 & 0.053 & -0.206 \\
\hline $\mathrm{Q}$ & 0.038 & 0.062 & -0.019 & -0.161 & -0.062 & -0.067 & -0.222 & -0.103 & 0.174 & -0.045 & -0.056 \\
\hline Moho & 0.322 & -0.255 & 0.042 & 0.417 & 0.117 & -0.061 & 0.184 & 0.048 & 0.070 & -0.178 & 0.177 \\
\hline Asten & 1 & -0.269 & 0.281 & 0.273 & 0.311 & -0.113 & -0.034 & -0.102 & 0.311 & -0.264 & 0.359 \\
\hline QUAR & -0.269 & 1 & -0.768 & -0.509 & -0.731 & 0.136 & -0.620 & 0.158 & -0.210 & -0.003 & -0.753 \\
\hline HPA & 0.281 & -0.768 & 1 & 0.478 & 0.962 & -0.098 & 0.488 & -0.049 & 0.241 & 0.127 & 0.898 \\
\hline $\mathrm{H}$ & 0.273 & -0.509 & 0.478 & 1 & 0.569 & 0.026 & 0.425 & -0.026 & 0.145 & -0.098 & 0.738 \\
\hline NPA & 0.311 & -0.731 & 0.962 & 0.569 & 1 & -0.059 & 0.469 & 0.011 & 0.243 & 0.134 & 0.936 \\
\hline $\mathrm{K}_{\mathrm{int}}$ & -0.113 & 0.136 & -0.098 & 0.026 & -0.059 & 1 & 0.066 & 0.027 & 0.009 & 0.104 & -0.035 \\
\hline RCM95 & -0.034 & -0.620 & 0.488 & 0.425 & 0.469 & 0.066 & 1 & -0.206 & 0.054 & 0.024 & 0.505 \\
\hline $\mathrm{K}_{\text {int }} 95$ & -0.102 & 0.158 & -0.049 & -0.026 & 0.011 & 0.027 & -0.206 & 1 & -0.120 & 0.189 & -0.033 \\
\hline $\mathrm{ACD}$ & 0.311 & -0.210 & 0.241 & 0.145 & 0.243 & 0.009 & 0.054 & -0.120 & 1 & -0.099 & 0.264 \\
\hline LIT & -0.264 & -0.003 & 0.127 & -0.098 & 0.134 & 0.104 & 0.024 & 0.189 & -0.099 & 1 & 0.089 \\
\hline$P_{10}$ & 0.359 & -0.753 & 0.898 & 0.738 & 0.936 & -0.035 & 0.505 & -0.033 & 0.264 & 0.089 & 1 \\
\hline
\end{tabular}

Note: see Table 6 for abbrevations. 


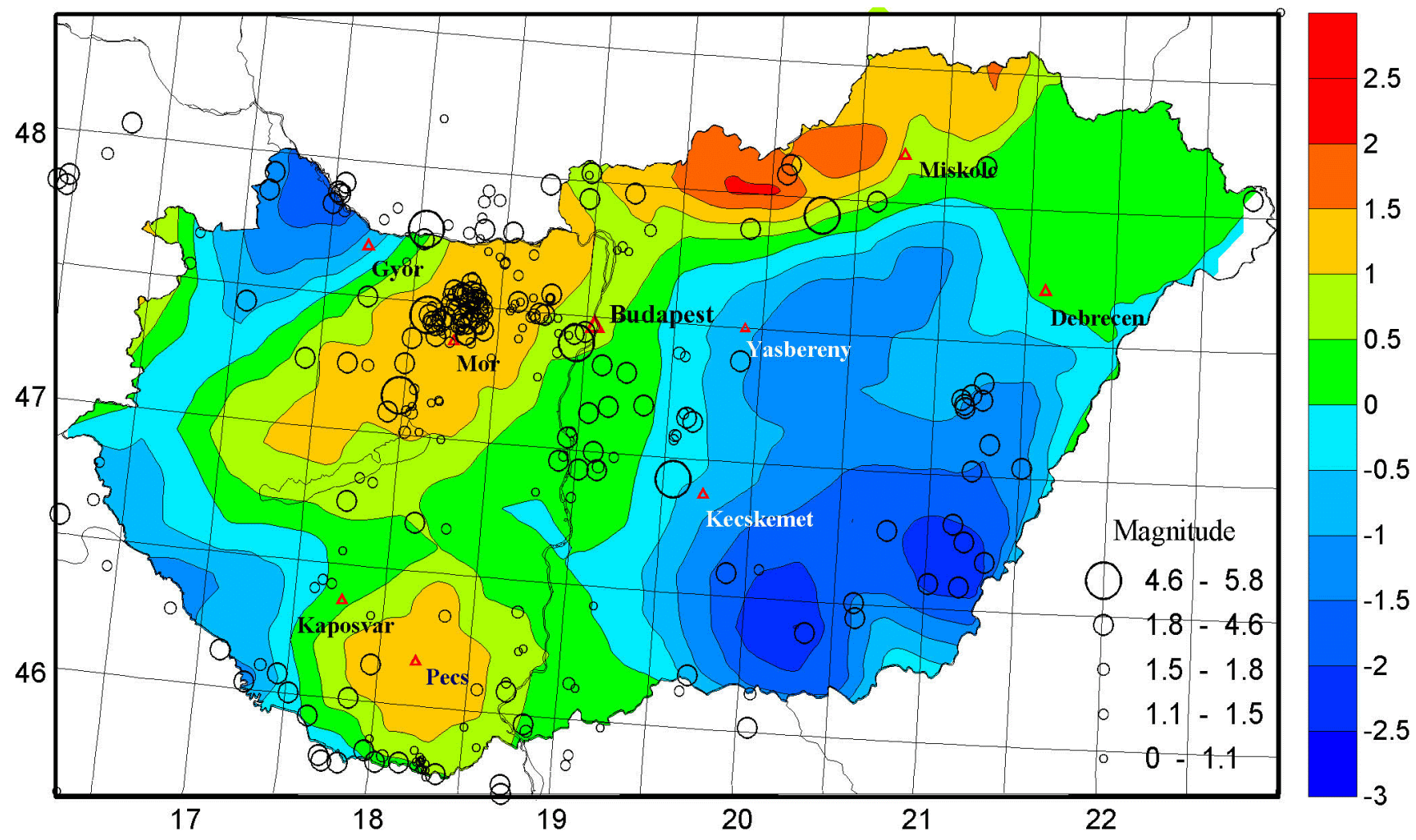

Figure 17. Map of the first factor, variant 1.

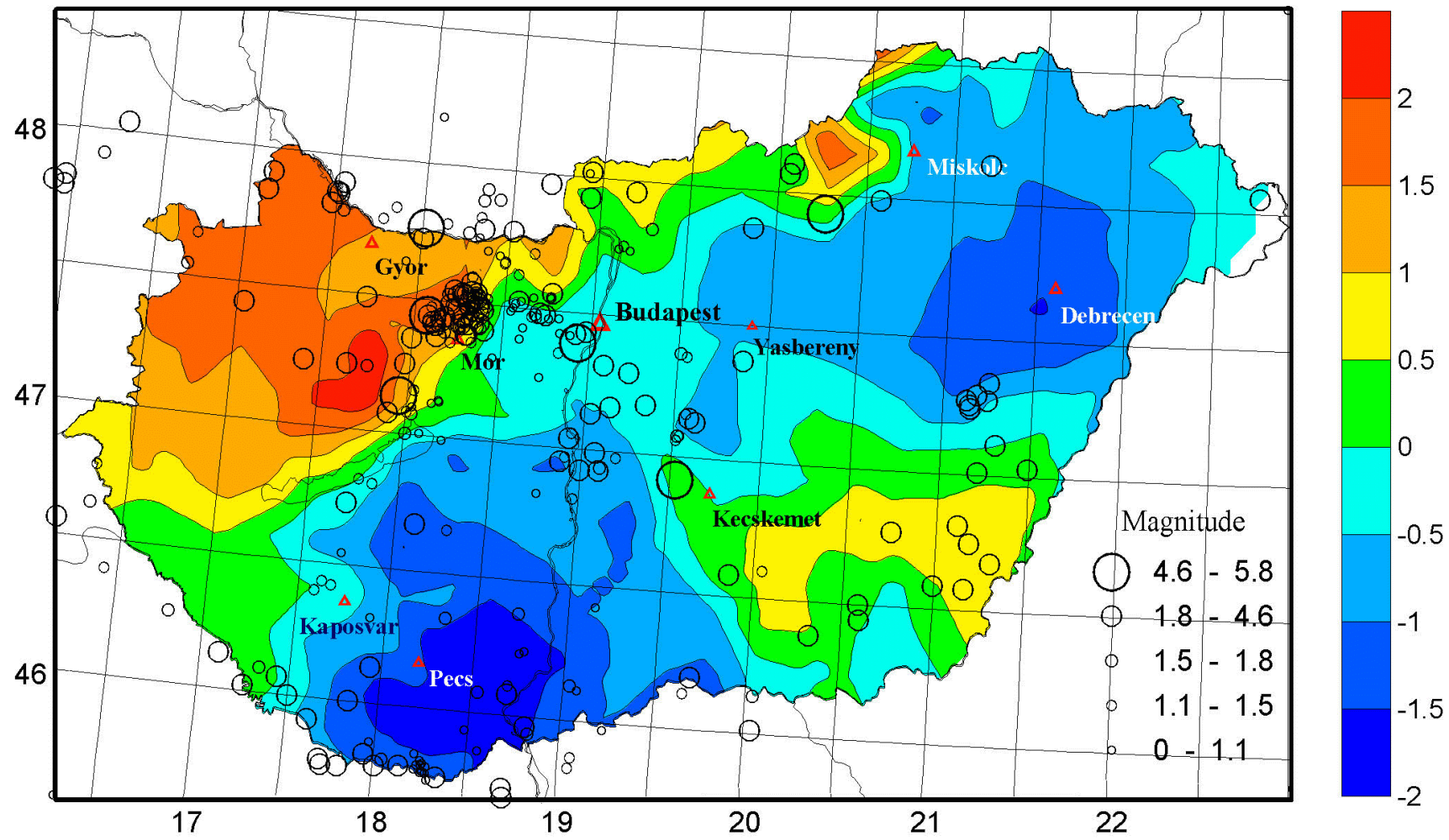

Figure 18. Map of the second factor, variant 1. 


\section{Hierarchical Cluster Analysis}

Dendrogram using Average Linkage (Between Groups) Rescaled Distance Cluster Combine

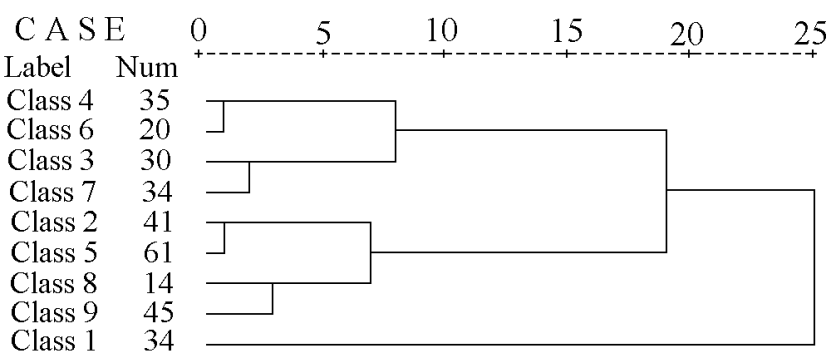

Figure 19. Cluster diagram based on the results of factor analysis, variant 1.

1984; Grachev and Dobrzhinetsksaya, 1987]. The geodynamic zoning scheme shown in Figure 20 was constructed as a result of two-factor cluster analysis (Figure 19).

The second zoning variant involves the following parame-
Table 8. Matrix of factor loads for main parameters of the Carpathian-Balkan region, variance 1

\begin{tabular}{|l|rc|}
\hline \multirow{2}{*}{ Parameter } & \multicolumn{2}{|c|}{ Factors } \\
\cline { 2 - 3 } & $1(45,9 \%)$ & $2(30,5 \%)$ \\
\hline DGS & -0.94 & 0.02 \\
H & 0.61 & 0.48 \\
Q & 0.02 & -0.78 \\
Moho & 0.04 & 0.88 \\
CRU & 0.96 & -0.03 \\
\hline
\end{tabular}

ters: $N, q, K_{\text {int }}$ Moho2002, Cru and $V_{\mathrm{P}}$. As distinct from the preceding case, we excluded the parameter DGS (because of its correlation with CRU) and introduced the NVCM curvature intensity $K_{\text {int }}$. This variant yielded three main factors with a total weight of more than $80 \%$ (Table 9 ). The first two factors are virtually identical to the factors obtained in the preceding case (cf. Table 8), and factor 3, including the $K_{\text {int }}$ parameter alone, is new. Actually, comparison of

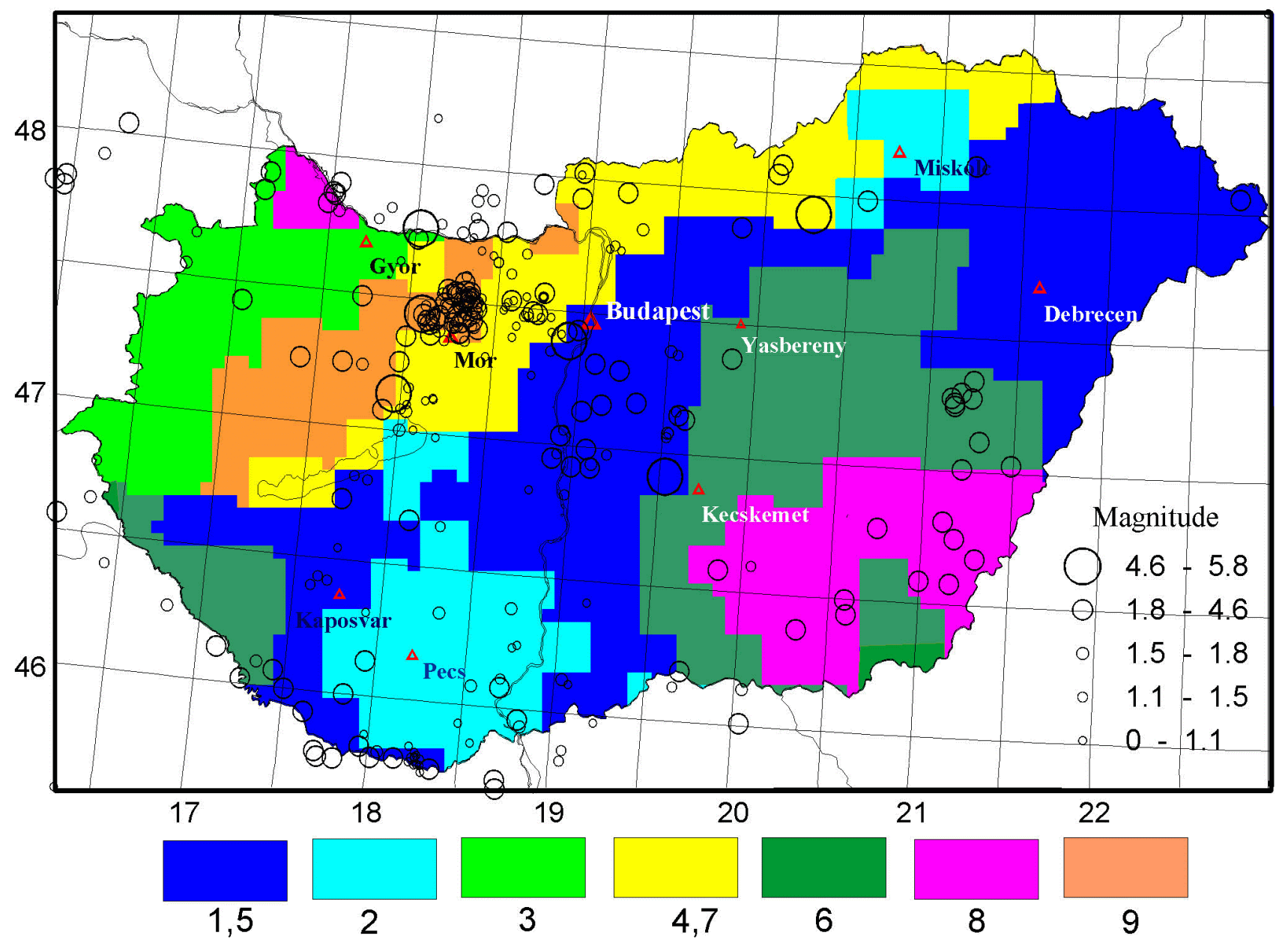

Figure 20. Scheme of geodynamic zoning of the Pannonian Basin, variant 1. 1, 2, 3 and other ciphers mean the number of classes (geodynamic regions). These classes are distinguished by the method of cluster analysis, see Figure 19. 


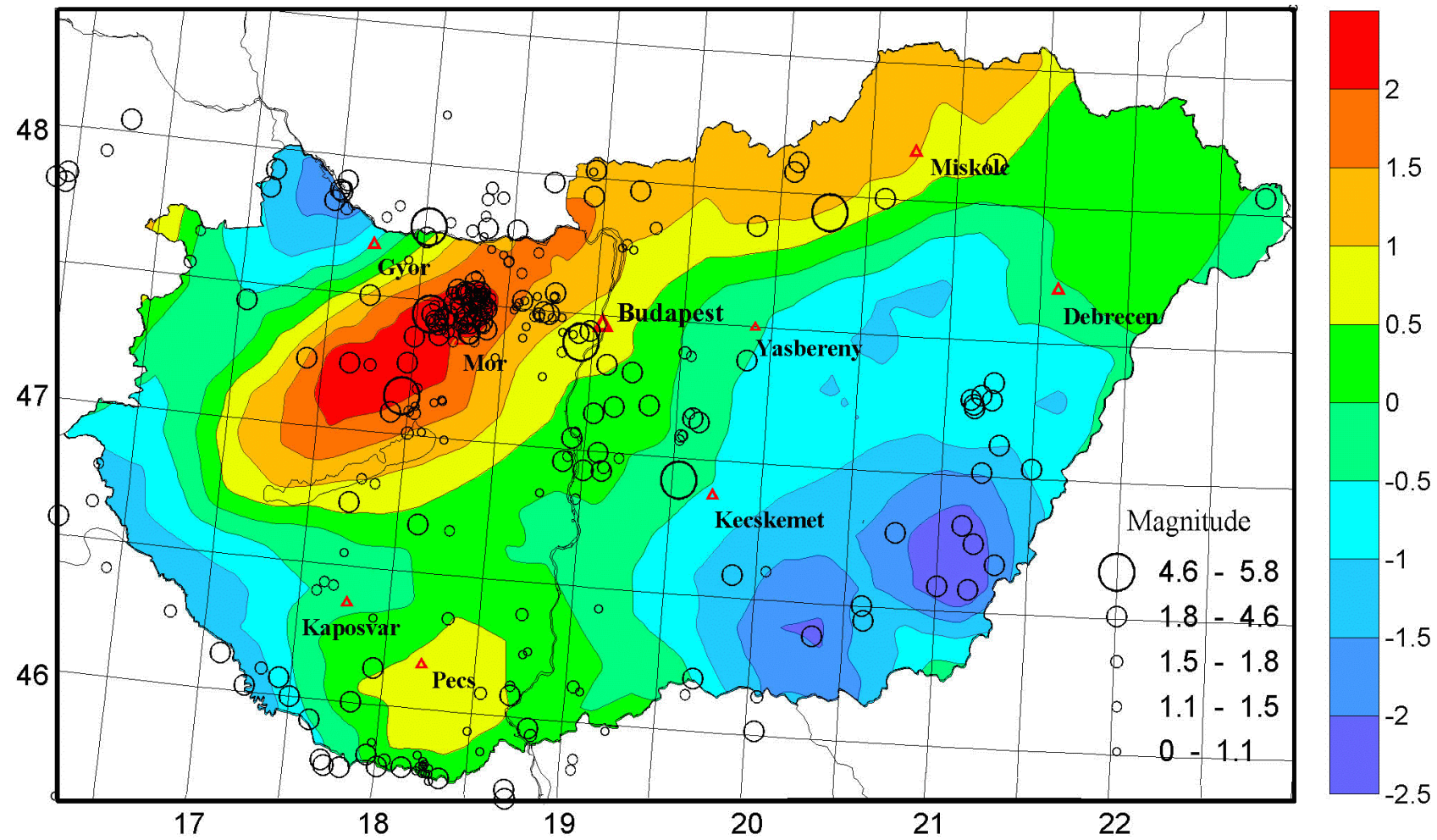

Figure 21. Map of the first factor, variant 2.

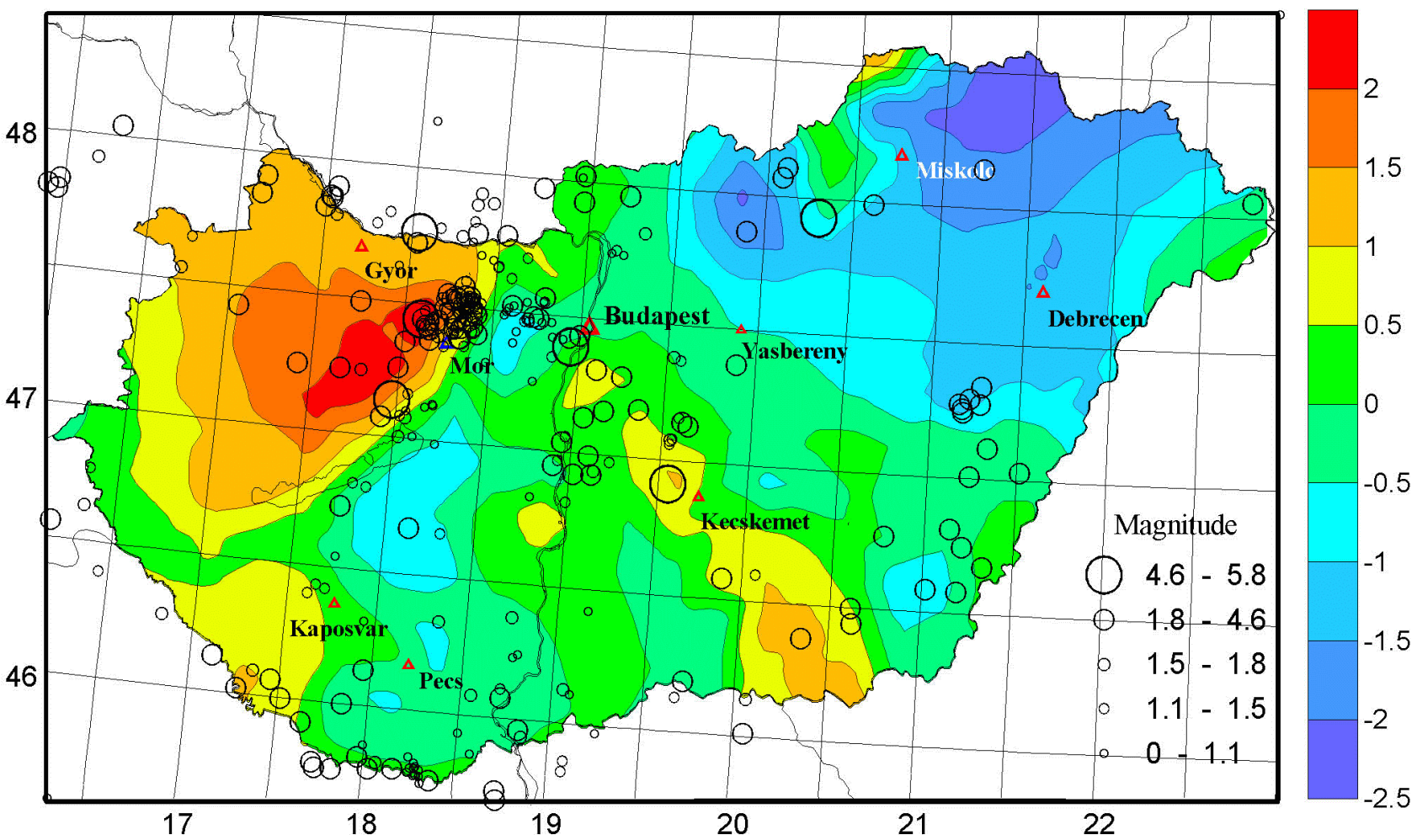

Figure 22. Map of the second factor, variant 2 . 


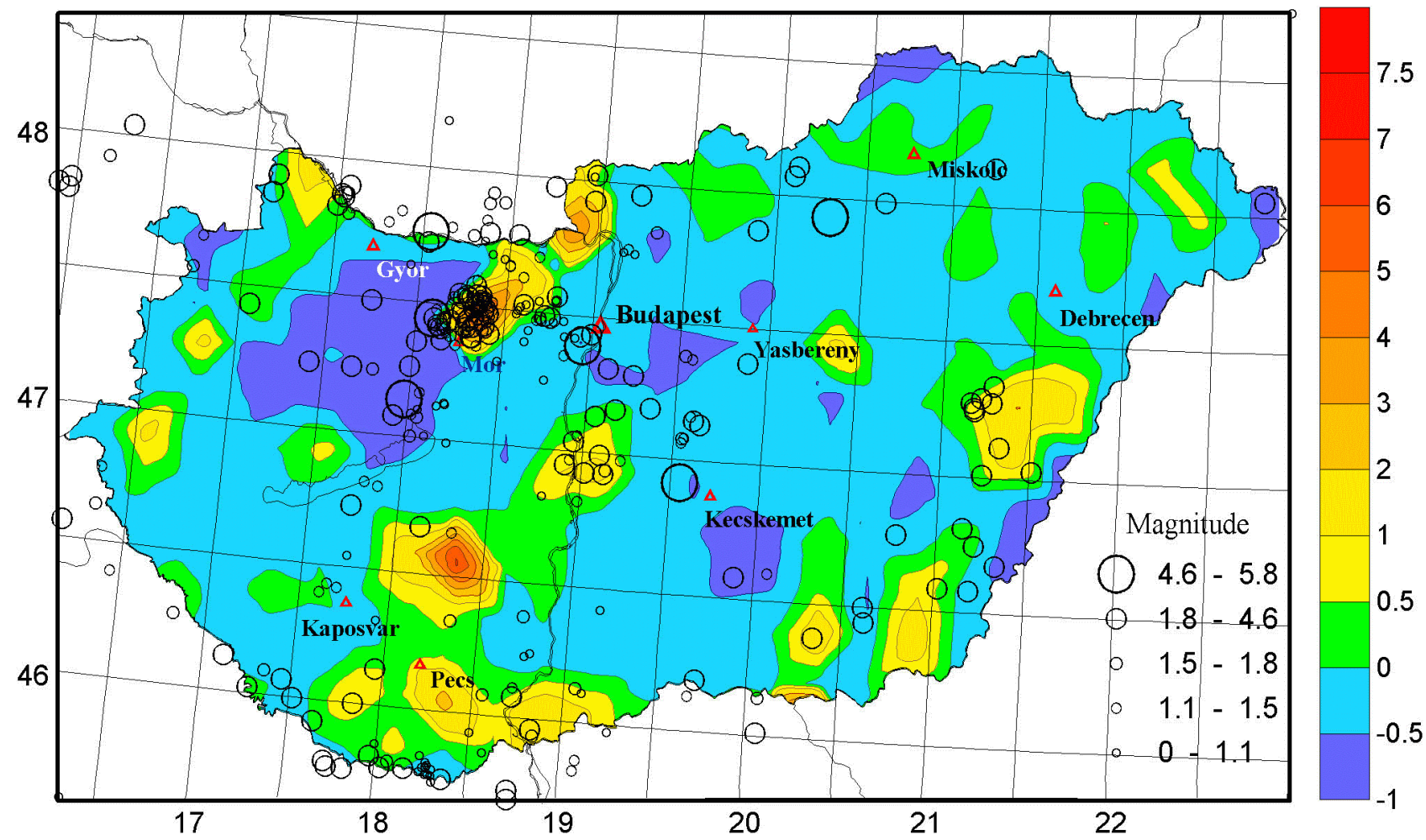

Figure 23. Map of the third factor, variant 2.

Figures 21 and 22 shows that the configuration pattern of the first two factors nearly coincides, whereas factor 3 is characterized by local zones of positive and negative curvatures observable against the background of $K_{\text {int }}$ values close to zero (Figure 23).

The three-factor cluster analysis (Figure 24) resulted in the construction of the geodynamic regionalization scheme (Figure 25) incorporating various types of the Pannonian basin volcanism.

In comparing the resulting two schemes of the Pannonian

\section{Hierarchical Cluster Analysis}

Dendrogram using Ward Method Rescaled Distance Cluster Combine

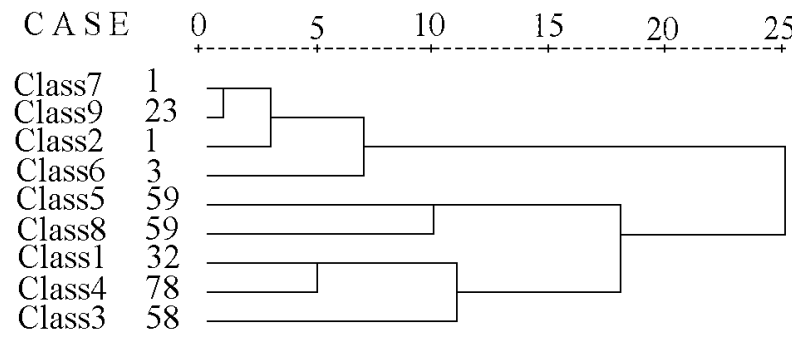

Figure 24. Cluster diagram based on the results of factor analysis, variant 2 . basin geodynamic regionalization (Figures 20 and 25), we thought it appropriate to take into account the distribution of earthquake epicenters. For this purpose, we used events with $M>5$ and weak earthquakes over the period from 1995 through 2000 [Toth et al., 2001]; in particular, one of the geodynamic regionalization tasks consisted in elucidating the relation between seismic activity and deep processes. Of two maps, the second variant, incorporating NVCM curvature intensities, is preferable. In this case, most epicenters that form clusters rather than linear zones form two classes (Figure 25).

Table 9. Matrix of factor loads for main parameters of the Carpathian-Balkan region, variance 2

\begin{tabular}{|l|rrr|}
\hline \multirow{2}{*}{ Parameter } & \multicolumn{3}{|c|}{ Factors } \\
\cline { 2 - 4 } & $1(45.5 \%)$ & $2(23.2 \%)$ & $3(15.8 \%)$ \\
\hline $\mathrm{N}$ & 0.96 & -0.10 & -0.03 \\
$\mathrm{~K}_{\text {int }}$ & -0.01 & 0.06 & 0.99 \\
$\mathrm{CRU}$ & 0.95 & -0.13 & -0.02 \\
Moho2002 & 0.79 & 0.46 & 0.01 \\
$\mathrm{Q}$ & -0.18 & $-0,85$ & 0.04 \\
$\mathrm{P}_{\mathrm{n}}$ & -0.35 & 0.61 & 0.18 \\
\hline
\end{tabular}




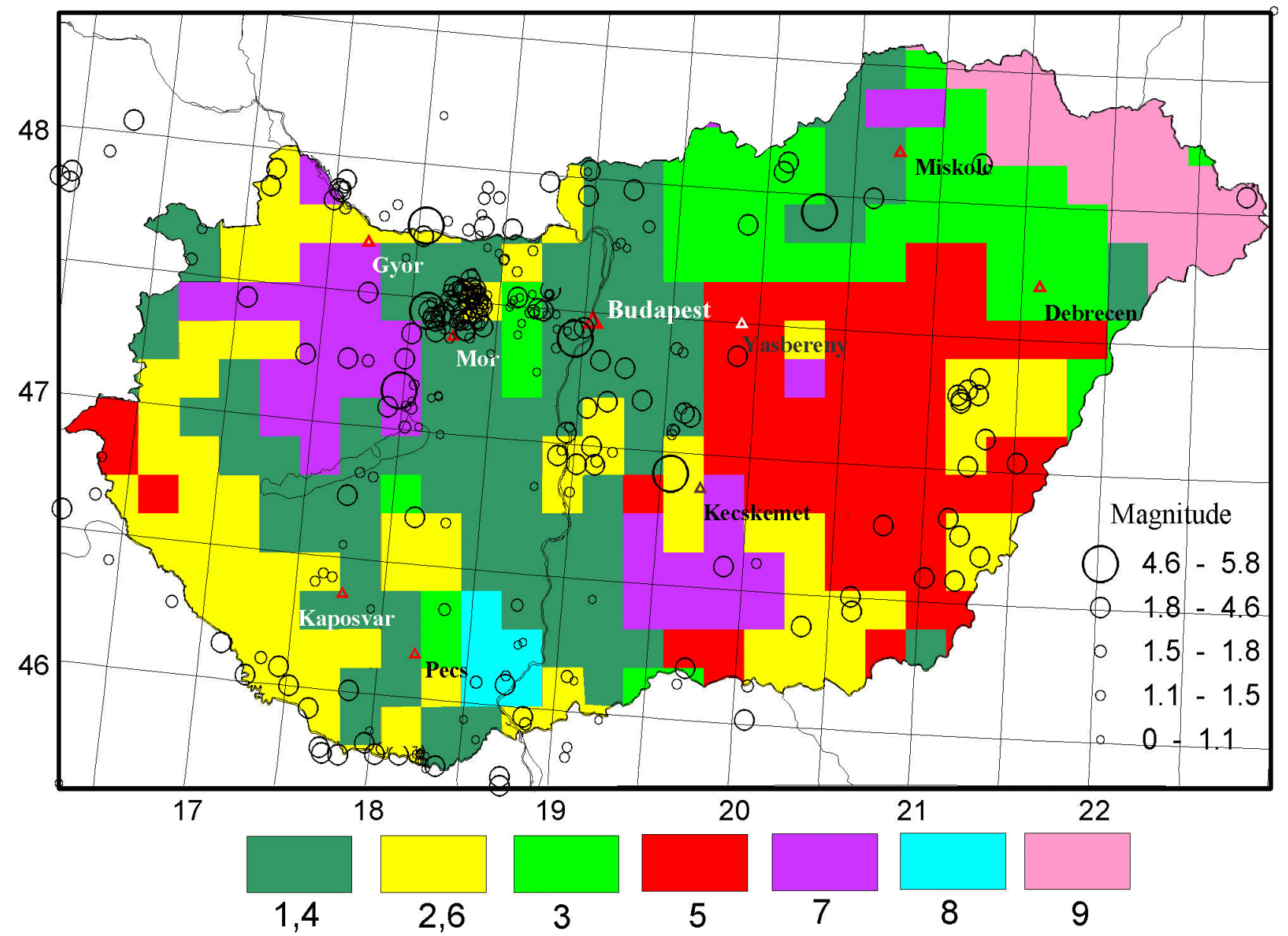

Figure 25. Scheme of geodynamic zoning of the Pannonian Basin, variant 1. 1, 2, 3 and other ciphers mean the number of classes (geodynamic regions). These classes are distinguished by the method of cluster analysis, see Figure 24.

\section{Conclusion}

The analysis of geological-geophysical data and petrogeochemical characteristics of neotectonic volcanism revealed a close relationship between the neotectonic structure of the Pannonian basin and the Earth's deep structure. The main features of the latter (a thin crust, the strong heating of the lithosphere and lower $P$ wave velocities in the upper mantle) can only be accounted for in terms of the model of a floating-up mantle diapir producing the extension of lithosphere (Figure 26) [Grachev et al., 1987a, 1987b, 1992]. Such a tectonic regime was named the synorogenic rifting [Grachev, 2000]. The existence of normal faults traceable from the surface to deep crust layers [Hajnal et al., 1996; Posgay et al., 1986] is independent evidence in favor of this model.

Of particular significance for the substantiation of the synorogenic rifting model is the alkali-basaltic volcanism which has been developed since the earliest Pannonian (11-
10.5 Ma), after the subduction had stopped and the previously widespread calc-alkaline volcanism had been localized within the Transcarpathian region. The chemistry of Pannonian basin basalts is fully consistent with petrogeochemical characteristics of continental rift basalts in concentrations of major, rare and rare earth elements [Grachev, 2000; Grachev et al., 1987b]. Moreover, ultrabasic xenoliths in the Pannonian basin basalts [Embey-Isztin et al., 2001; Falus et al., 2000; Magnitsky et al., 1988] belonging to the spinel lherzolite facies are also identical in composition to mantle xenoliths usually found in rift volcanics [Grachev, 1987a, $1987 \mathrm{~b}]$.

Results derived from recent studies of spinel lherzolite xenoliths from Pannonian basin basalts [Falus et al., 2000] showed that the ascent of the mantle diapir from depths of 90-120 km to 55-65 km took place recently. Although Falus et al. did not date this event, one can easily demonstrate that it coincided in time with the onset of the alkali-basaltic magmatism.

Thus, the entire complex of data presented in this work 


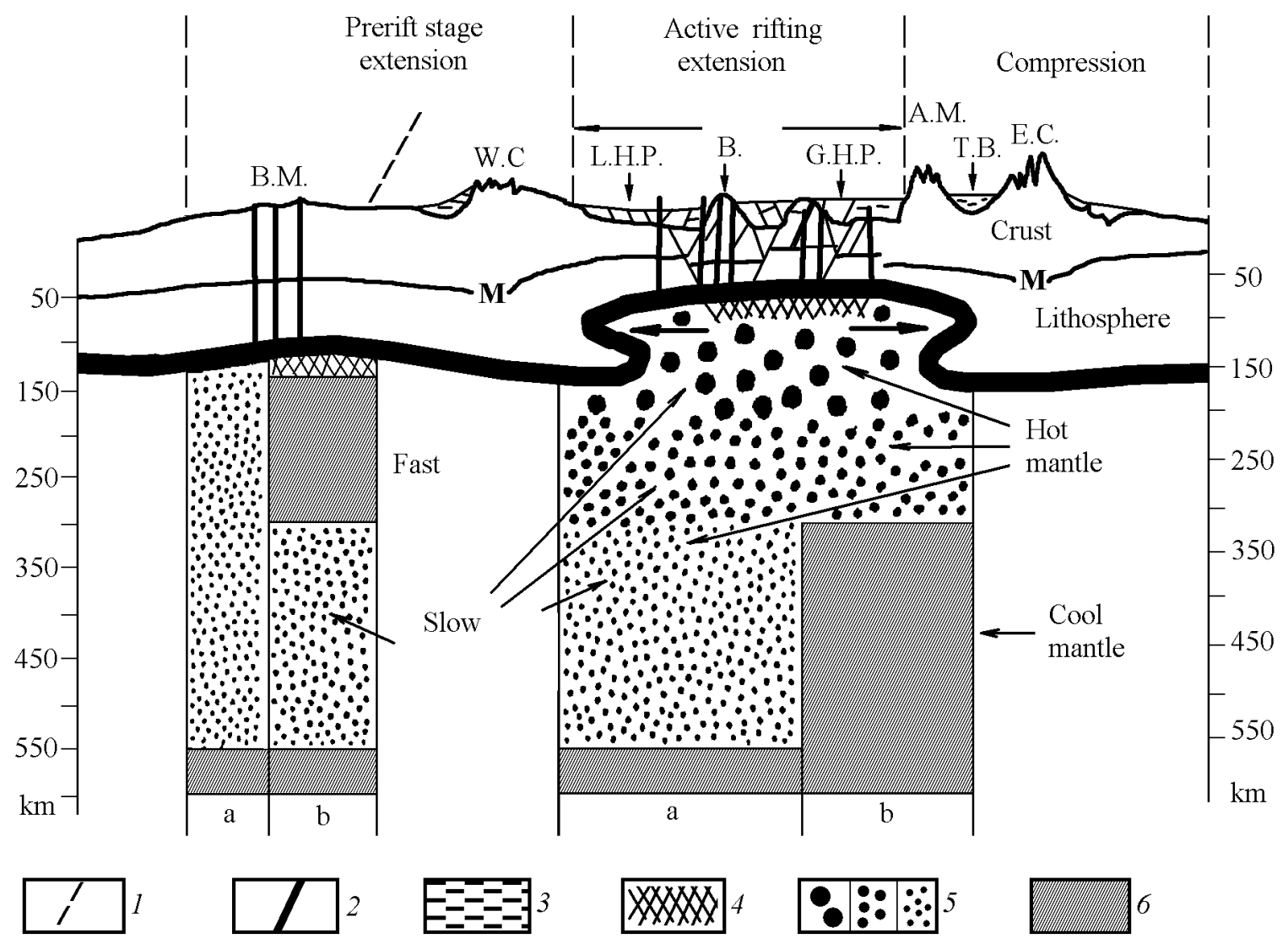

Figure 26. Geodynamic development model of the Pannonian basin, Carpathians and Bohemian Massif [Grachev, 2000]: (1) normal faults; (2) feeders and volcanoes; (3) sedimentary cover; (4) partial melting zone in the mantle; (5) low-velocity hot mantle (the larger the black dots, the hotter the mantle); (6) high-velocity cold mantle: (a) after Babuska et al. [1984], (b) after Hovland and Husebye [1982]; BM - Bohemian Massif; WC - Western Carpathians; LHP - Little Hungarian Plain; B - Bakony Mountains (Hungarian Midmountains); GHP - Great Hungarian Plain; AM - Apuceni Massif; TB - Transylvanian basin; EC - Eastern Carpathians.

indicates that evolutionary models of the Pannonian basin based on the passive response of lithosphere to external effects [Bada et al., 1999] are invalid.

The first results of geodynamic regionalization described in this work show the effectiveness of such treatment of the geological-geophysical database. This approach allows one to identify individual lithospheric blocks distinguished by a specific relationship between geological-geophysical parameters. This is clearly demonstrated by mapping main factors (Figures 17, 18, 21, 22, 23). In our opinion, this approach is beneficial to understanding the still-unclear origin of seismic activity of the Pannonian basin.

Acknowledgments. This work was supported by the Russian Foundation for Basic Research, Projects Nos 01-05-64380 and 0105-64381.

\section{References}

Adam, A., F. Horvath, and L. Stegena, Geodynamics of the Pannonian basin: Geothermal and electromagnetic aspects, Acta Geol. Acad. Sci. Hung., 21, 251-260, 1977.

Adam, A., K. Landy, and Z. Nagy, New evidence for the distribution of the electric conductivity in the Earth's crust and upper mantle in the Pannonian basin as a 'hot spot', Tectinophysics, 164, 361-368, 1989.

Alibert, C., J. Leterrier, M. Panasiuk, and J. L. Zimmermann, Trace and isotope geochemistry of the alkaline Tertiary volcanism in southwestern Poland, Lithos., 20, 311-321, 1987.

Arabadzijski, D., Ja. Vanko, T. Wyrzykowskij, et al., Map of Recent Vertical Movements of Bulgaria, Hungary, GDR, Poland, Romania, USSR, Czhechoslovakia, Scale 1:2 500 000, Moscow, 1986.

Aron, J., A Dunantuli-Kozephegyseg Pannonian Kepzodmenyel, Muszaki Konyvkiado, Budapest, 1980.

Babuska, V., J. Plomerova, and J. Sileny, Large-scale oriented structures in the subcrustal lithosphere of Central Europe, Ann. Geophys., 2, 649-662, 1984.

Bada, G., L. Fodor, B. Szekely, and G. Timar, Tertiary brittle faulting and stress field evolution in the Gerecse Mountains, northern Hungary, Tectonophysics, 255, 269-289, 1996. 
Bada, G., F. Horvath, P. Gerner, and I. Fejes, Review of the present-day geodynamics of the Pannonian basin: Progress and problems, J. Geodynamics, 27, 501-527, 1999.

Badawy, A., $P$-wave spectra of the Fuzesgyamart, eastern Hungary earthquake sequence, J. Seismol., 4, 49-58, 2000.

Badawy, A., F. Horvath, and L. Toth, Source parameters and tectonic interpretation of recent earthquakes (1995-1997) in the Pannonian basin, J. Geodynamics, 31, 87-103, 2001.

Balla, Z., The Carpathian loop and the Pannonian basin: A kinematic analysis, Geophys. Trans., 30, 313-355, 1984.

Balla, Z., Is there any proof for Quaternary tectonism in the Paks area, Hungary, (In connection with the publication of the volume "Seismic safety of the Paks nuclear power plant," Acta Geol. Hung., 42, 309-326, 1999.

Balla, Z., and L. Havas, A matrai eltolodas, Foldtani Kozlony, 112, 197-207, 1982.

Balla, Z., Early Alpine geodynamics of the Carpathian-Pannonian region, in Tectonics, Section C.07.27, Int. Geol. Congr. (in Russian), pp. 63-73, 1984.

Balogh, K., Problems of the origin of the Pre-Tertiary Great Tectonic Units of Hungary, Anu. Inst. Geol. si Geofiz., 60, 23-29, 1983.

Bazhenov, M. L., and V. S. Burtman, On the origin of the northern Carpathian arc (in Russian), Dokl. Akad. Nauk SSSR, 255, 681-685, 1980.

Beer, M. A., and G. I. Shcherba, Late Alpine history of the Eastern Carpathians development (in Russian), Byull. MOIP, Otd. Geol., 59, 47-62, 1984.

Berczi, J., and R. L. Phillips, Processes and depositional environments within Neogene deltaic-lacustrine sediments, Pannonian Basin, Southeast Hungary, Geophys. Trans., 31, 55-74, 1985.

Bergerat, F., From pull-apart to the rifting process: The formation of the Pannonian Basin, Tectonophysics, 157, 271-280, 1989.

Birkenmayer, K., Carpathians, in Mesozoic-Cenozoic Foldbelts (in Russian), pp. 163-199, Mir, Moscow, 1977.

Bleahu, M. D., P. Boccaletti, P. Manetti, and S. Peltz, Neogene Carpathian arc: A continental arc displaying the features of an island arc, J. Geophys. Res., 78, p. 5025, 1973.

Blusztajn, J., and S. R. Hart, Sr, Nd and Pb isotopic character of Tertiary basalts from southwest Poland, Geochim. Cosmochim. Acta, 53, 2689-2696, 1989.

Boccaletti, M., F. Horvath, and M. Loddo, The Tyrrhenian and Pannonian basins: A comparison of two Mediterranean interarc basins, Tectonophysics, 35, 45-69, 1976.

Bodri, B., Thermal state, rheology and seismicity in the Pannonian basin, Hungary, J. Geodynamics, 21, 309-328, 1996.

Brimich, L., and L. A. Latynina, Strain measurements in Slovakia (in Russian), Fiz. Zemli, (12), 1988.

Bronguleev, V. V., A. F. Grachev, I. V. Kalashnikova, and V. A. Magnitsky, Recent crustal movements, neotectonics and physical fields in the Carpathian-Balkan region: Correlation analysis (in Russian), Fiz. Zemli, (7), 3-12, 1984.

Burchfiel, B. C., and I. Royden, Carpathian foreland fold and thrust belt and its relation to Pannonian and other basins, $A m$. Assoc. Petrol. Geol. Bull., 66, 1179-1195, 1982.

Burtman, V.S., Kinematics of the Carpathian structural loop (in Russian), Geotektonika, (3), 17-31, 1984.

Buryanov, V. B., V. V. Gordienko, O. V. Zavgorodnaya, et al., The tectonosphere of the Carpathian-Dinarides region from a physical dataset (in Russian), Geofiz. Zh., (2), 48-54, 1984.

Bus, Z., Gy. Szeidovitz, and F. Vaccari, Synthetic seismogram based deterministic seismic zoning for the Hungarian part of the Pannonian basin, Pure Appl. Geophys., 157, 205-220, 2000.

Cermak V., and L. Bodri, Temperature structure of the lithosphere based on second temperature modeling applied to Central and Eastern Europe, J. Geodynamics, 5, 133-163, 1986.

Chalot-Prat, F., and R. Girbacea, Partial delamination of continental mantle lithosphere, uplift-related crust-mantle decoupling, volcanism and basin formation: A new model for the Pliocene-Quaternary evolution of the southern East Carpathians, Romania, Tectonophysics, 327, 83-107, 2000.

Cox, K. G., J. D. Bell, and R. J. Pankhurst, Interpretation of
Igneous Rocks (in Russian), Nedra, Moscow, 1982.

Csaszar, G., J. Haas, J. Halamai, et al., The role of late Alpine tectonic phases in the geological history of Hungary, Anu. Inst. Geol Geofiz., 60, 51-56, 1983.

Csontos. L.. Tertiary tectonic evolution of the Intra-Carpathian area: A review, Acta Vulcanol., 7, 1-14, 1995.

Dewey, J. F., W. C. Pitman III, W. B. F. Ryan, and J. Bonnin, Plate tectonics and evolution of the Alpine System, Geol. Soc. Am. Bull., 84, 3137-3180, 1973.

Ekman, M., Gaussian and mean curvatures of postglacial land uplift as expanded in surface spherical harmonics and the origin of earthquakes in Fennoscandia, in 5th Int. Symp. "Geodesy and Physics of the Earth," Part III, pp. 55-71, Potsdam, 1985.

Elston, D. P., G. Hamor, A. Jambor, et al., Magnetostratigraphy of Neogene strata penetrated in two deep core holes in the Pannonian Basin: Preliminary results, Geophys. Trans., 31, 75-88, 1985.

Embey-Isztin, A., G. Dobosi, R. Altherr, and H.-P. Meyer, Thermal evolution of the lithosphere beneath the western Pannonian Basin: Evidence from deep-seated xenoliths, Tectonophysics, 331, 285-306, 2001.

Falus, G., Cs. Szabo, and O. Vaselli, Mantle upwelling within the Pannonian Basin: evidence from xenolith lithology and mineral chemistry, Terra nova, 12, 295-302, 2000.

Fulop, J., K. Brezsnyansky, and J. Haas, The new map of basin basement of Hungary, Acta Geol. Hung., 30, 3-20, 1987.

Fulop, J., and V. Dank, Eds., Precenozoic Basement Map of Hungary. 1:500 000, 1987.

Geochemistry, petrophysics and origin of young volcanics of Soviet Carpathians, 188 p., Kiev, Kiev Univ. Press., 1976.

Gill, J. B., Orogenic Andesites and Plate Tectonics, SpringerVerlag, Berlin, 1981.

Gofshtein, I. D., Neotectonics of the Carpathians (in Russian), AN SSSR, Kiev, 1964.

Grachev, A. F. 2nd ed., Rift Zones of the Earth (in Russian), Nedra, Moscow, 1987a.

Grachev, A. F., Heterogeneity of the continental lherzolite mantle estimated from the ultrabasic xenoliths study, in Physics and interior structure of the Earth (in Russian), pp. 22-43, Nedra, Moscow, 1987b.

Grachev, A. F., Late Cenozoic volcanism of the Pannonian basin and its geodynamic position, Physics Solid Earth, 2003 (in press).

Grachev, A. F., The Pannonian rift, in Neotectonics, Geodynamics and Seismicity of North Eurasia (in Russian), pp. 171-185, Probel, Moscow, 2000.

Grachev, A. F., and L. F. Dobrzhinetskaya, Structural anisotropy of mantle xenoliths from Neogene Central Europe volcanics and its implications for the interpretation of azimuthal seismic anisotropy of lithosphere, in Deep Xenoliths and the Structure of the Lithosphere (in Russian), pp. 178-193, Nauka, Moscow, 1987.

Grachev, A. F., and V. O. Mikhailov, On the origin of intraplate sedimentary basins of an isometric shape, in Intraplate Phenomena in the Earth's Crust (in Russian), pp. 159-166, Nauka, Moscow, 1988.

Grachev, A. F., and V. I. Mishin, Construction of neotectonics maps based on the trend analysis (in Russian), Geomorfologiya, (2), 63-70, 1975.

Grachev, A. F., V. A. Magnitsky, and I. V. Kalashnikova, Recent and Late Cainozoic geodynamics of the Central Europe, in $A b$ stracts, 7th Int. Symposium on Recent Crustal Movements of the Earth, pp. 48-49, Tallinn, 1986.

Grachev, A. F., V. A. Magnitsky, and I. V. Kalashnikova, Recent crustal movements, neotectonics and physical fields in the Carpathian-Balkan region: Analysis of neotectonic sedimentation and volcanism (in Russian), Fiz. Zemli, (8), 3-20, 1987a.

Grachev, A. F., V. A. Magnitsky, and I. V. Kalashnikova, Recent crustal movements, neotectonics and physical fields in the Carpathian-Balkan region: Composition and state of the upper mantle and the origin of recent and neotectonic activity (in Russian), Fiz. Zemli, (9), 3-15, 1987b.

Grachev, A. F., N. K. Frolova, Sz. Sz. Grigorjan, et al., The 
Specification of Geological Position and Nature of the Fault in the Paks NPP District, Manuscript, Paks Atomeromu Rt., Foldrenges Proekt Jelentestara, Paks, 1987c.

Grachev, A. F., V. A. Magnitsky, and I. V. Kalashnikova, Recent crustal movements and neotectonics of the Pannonian basin, in 6th Int. Symp. "Geodesy and Physics of the Earth," Abstracts, pp. 31-32, Potsdam, 1988.

Grachev, A. F., V. A. Magnitsky, I. V. Kalashnikova, and I. L. Lapushonok, Recent crustal movements in relation to seismicity in the Pannonian basin (in Russian), Fiz. Zemli, (9), 3-8, 1989a.

Grachev, A. F., M. E. Bojarskij, V. I. Bune, et al., Report on the Seismic Hazard of the Paks NPP, Manuscript, Paks Atomeromu Rt., Foldrenges Proekt Jelentestara, Paks, 1989b.

Grachev, A. F., I. V. Kalashnikova, and V. A. Magnitsky, Recent crustal movements and seismicity (in Russian), Fiz. Zemli, (11), 3-12, 1990.

Grachev, A. F., V. A. Magnitsky, V. O. Mikhailov, and T. V. Romanyuk, Geodynamic evolution of the Pannonian basin: Synthesis of geological and geophysical data and numerical modeling, in Abstracts. Int. Symp., Moscow, 1992.

Grachev, A. F., V. A. Magnitsky, Sh. A. Mukhamediev, and S. L. Yunga, Tensor characteristics of recent bending deformations and basement surface curvatures of the East European platform (in Russian), Dokl. Ross. Akad. Nauk, 340, 250-255, 1995a.

Grachev, A. F., V. A. Magnitsky, Sh. A. Mukhamediev, and S. L. Yunga, Tensor characteristics of neotectonic bending deformations and basement surface curvatures of the East European platform (in Russian), Dokl. Ross. Akad. Nauk, 340, 389-395, 1995b.

Grachev, A. F., V. A. Magnitsky, and V. A. Nikolaev, Interpretation of data on recent crustal movements in the Pannonian basin (in Russian), Dokl. Ross. Akad. Nauk, 381, 532-535, 2001a.

Grachev, A. F., V. A. Magnitsky, and V. A. Nikolaev, Recent crustal movements in the Pannonian basin and the problem of their interpretation, Izvestiya, Phys. Solid Earth, 37, 987-994, 2001b.

Gutdeutsch, R., and K. Aric, Tectonic Block Models Based on the Seismicity in the East Alpine-Carpathian and Pannonian Area, Wien, 1986 (in press).

Hajnal, Z., B. Reilkoft, K. Posgay, et al., Crustal-scale extension in the central Pannonian basin, Tectonophysics, 264, 191-204, 1996.

Hippolyte, J.-C., D. Badescu, and P. Constantin, Evolution of the transport direction of the Carpathian belt during its collision with the East European platform, Tectonics, 18, 1120-1138, 1999.

Horvath, F., Neotectonics of the Pannonian basin and the surrounding mountain belts: Alps, Carpathians and Dinarides, Annales Geophys., 2, 147-154, 1984.

Horvath, F., and L. Stegena, The Pannonian basin: A Mediterranean interarc basin, in Proc. Int. Symposium of the Structural History of the Mediterranean basins, pp. 333-340, 1977.

Horvath, F., A. Szalay, P. Dovenyi, and J. Rumpler, Structural and thermal evolution of the Pannonian basin: An overview, in Thermal Modelling in Sedimentary Basins, J. Burrus, Ed., pp. 339-358, Technip, Paris, 1986.

Hovland, J., and E. S. Husebye, Upper mantle heterogeneities beneath eastern Europe, Tectonophysics, 90, 137-151, 1982.

Huller, H.-J., Petrographische Untersuchungen uber die Entstehung von Basaltglasern in Basaltischen Gesteinen des Steinberges bei Feldbach (Steiermark, Osterreich), Inauguraldissertation zur Erlangung des Doktorgrades der Philosophischen Fakultat der Karl-Franzens-Universitat in Graz, Graz, 1974.

Jambor, A., Review of the geology of the s.l. Pannonian formations in Hungary, Acta Geol. Hung., 32, 269-324, 1989.

Jasko, S., A Pannonian-medence besullyedese es felto ltedese a neegenben, in M. All. Fodtani Intezet Evi Jelentese AZ, Evrol., pp. $133-146,1973$.

Joo, I., Vertical movements in Hungary, Geod. Kartogr., (9), 3-9, 1998

Jugovics, L., Chemical features of the basalts in Hungary, Ann.
Rep. Hung. Geol. Inst., pp. 431-470, 1974.

Irvine, T. N., and W. R. A. Baragar, A guide to the chemical classification of the common volcanic rocks, Can. J. Earth Sci., 8, 523-548, 1971

Kassai, M., Adatok a scheffer-fele "Dunantul-Bacskai paleozoos kuszob", valamint a Zilahi-Sebess L. Altal levezetett gravitacios anomalia-menet kerdeseihez. 1982, M. All. Foldt. Int. Evi Jel., pp. 527-536, 1980-Rol.

Khain, V. E., Regional Geotectonics of the Alpine Mediterranean Belt (in Russian), Nedra, Moscow, 1984.

Kilenyi, E., and J. Rumpler, Pre-tertiary basement relief map of Hungary, Geophys. Trans., 30, 425-428, 1984.

Kleb, B., A Mecseki Pannon Foldtana, in Evkonyve, MAFI, Budapest, pp. 751-944, 1973.

Kleb, B., Eger epites foldtana (kandidehen erteheres), Budapest, pp. 138-151, 1980.

Kokai, A., DK-Duntantul Foldtani-Szerkezeti Viszonyal a Landsat-1 Muholdfelvetel Kiertekelese Alpjan, M. All. Foldt. Int. Evi Jel. 1980-Rol, pp. 501-508, 1982.

Kokay, J., Hegysegszerkezeti mozgasviszonyok Varpalota kornyeken. Foldt. Kozlony, LXXXYI, I, p. 17-27, 1956.

Kokay, J., Geomechanical investigations of the southeastern margin of the Bakony mountains and the age of the Liter fault line, Acta Geol. Acad. Sci. Hung., 20, 245-257, 1976.

Kokay, J., Tectonikai-geomechanicai vizsgalatotok a bantapusztaimedense teruleten Varpalota O. Mafi Evi Jelentese AZ, pp. 43$50,1983$.

Kuno, H., Differentiation of basalt magmas, in Basalts, vol. II, pp. 624-688, Wiley, New York, 1968.

Lankreijer, A., M. Bielik, S. Cloeting, and D. Majcin, Rheology predictions across the western Carpathians, Bohemian massif and the Pannonian basin: Implications for tectonic scenarios, Tectonics, 18, 1139-1153, 1999.

Lippolt, H.-J., K-Ar determination and correlation of Tertiary volcanic activity in Central Europe, Geol. J., 52, 113-135, 1982.

Lisle, R. J., Detection of zones of abnormal strains in structures using Gaussian curvature analysis, Am. Assoc. Petrol. Geol. Bull., 78, 1811-1819, 1994.

Lithosphere of Central and Eastern Europe: Generalization of Research Results (in Russian), Naukova Dumka, Kiev, 1993.

Machel, M., Ed., Tectonics of the Carpathian-Balkan Region, Geol. Inst. Dionyz. Stur., Bratislava, 1974.

Magnitsky, V. A., Physical origin of some types of vertical crustal movements, in Recent Crustal Movements (in Russian), pp. 4755, Tartu, 1965

Magnitsky, V. A., A. F. Grachev, I. V. Kalashnikova, and V. V. Bronguleev, Recent crustal movements of the CarpathianBalkan region and their relationship with neotectonic movements and geophysical fields, in Proc. 5th Int. Symposium on Geodesy and Physics of the Earth, part III, pp. 113-123, Potsdam, 1985.

Magnitsky, V. A., V. B. Sollogub, A. F. Grachev, et al., Lithosphere of Central and Eastern Europe: Geodynamics (in Russian), Naukova Dumka, Kiev, 1988.

Maldarescu, J., M. Atanasiu, and M. Secluman, Significations de la presence de certains nodules de peridotites dans les basalts de Rascosul de Jos, Rev. Roum. Geol. Geophys. Geograph., 27, 9-14, 1983.

Maleev, E. F., Neogene Volcanism in the Trans-Carpathian Region (in Russian), Nauka, Moscow, 1964.

Malovitskii, Ya. P., Ed., Geology and Hydrology of the Western Black Sea (in Russian), Bulg. Acad. Sci., Sofia, 1979.

Map of recent vertical crustal movements in the CarpathianBalkan region on a scale of 1:1000 000, Budapest, 1979.

Marton, P., Hungarian National Report on IASPEI (1995-1998), Acta Geod. Geophys. Hung., 34, 319-348, 1999.

Mattick, R. E., J. Rumpler, and R. L. Phillips, Seismic stratigraphy of the Pannonian basin in southeastern Hungary, Geophys. Trans., Special Ed., 31, 13-54, 1985.

Meshcheryakov, Yu. A., Ed., Map of recent vertical crustal movements in Eastern Europe on a 1:2 500000 scale (in Russian), GULG, Moscow, 1973. 
Mesko, A., Reduced regional Bouguer-anomaly map of Hungary, Acta Geod. Geophys. Mont. Hung., 23, 89-95, 1988.

Meszaros, J., Nagymeretu vizsrintes eltolodas a Bakony nyngati reszen es szerope a nyezsanyagkutatasbau, pp. 517-526, Budapest, MAFI, EVI JEL, 1980-ROL.

Meulenkamp, J. E., M. Kovac, and I. Cicha, On Late Oligocene to Pliocene depocentre migrations and the evolution of the Carpathian-Pannonian system, Tectonophysics, 266, 301-317, 1996.

Milanovskii E. E., and N. V. Koronovski, Orogenic volcanism and tectonics of the Alpine belt, Moscow, Nedra, 1973.

Molasse Formation in Hungary, Budapest, 1981.

Mukhamediev, Sh. A., Lithosphere bending as the origin of some seismotectonic phenomena (in Russian), Dokl. Akad. Nauk SSSR, 324, 986-989, 1992.

Nagymarosy, A., Chrono and biostratigraphy of the Pannonian basin: A review based mainly on data from Hungary, Earth Evol. Sci., (3-4), 183-194, 1981.

Nesterov, A. N., and T. B. Yanovskaya, Horizontal heterogeneities in the southeastern Europe lithosphere from surface wave observations (in Russian), Fiz. Zemli, (11), 3-15, 1988.

Nikolaev, V. A., Geodynamic regionalization of the East European platform, in Tectonics and Geophysics of the Lithosphere (in Russian), vol. 2, pp. 56-58, Geos, Moscow, 2002.

Nothard, S., D. McKenzie, J. Haines, and J. Jackson, Gaussian curvature and relationship between the shape and the deformation of the Tonga slab, Geophys. J. Int., 127, 311-327, 1996.

Ofoegbu, G. I., and D. A. Ferrill, Mechanical analyses of listric normal faulting with emphasis on seismicity assessment, Tectonophysics, 284, 65-77, 1998.

Onuoha, K. M., A comparison of the thermal and mechanical structure of the lithosphere beneath the Bohemian massif and the Pannonian basin, J. Geophys., 49, 212-216, 1981.

Oxburgh, E. R., R. K. O'Nions, and R. I. Hill, Helium isotope in sedimentary basins, Nature, 324, 632-635, 1986.

Oxburgh, E. R., and R. K. O'Nions, Helium loss, tectonics and the terrestrial heat budget, Science, 237, T29-T34, 1987.

Pajdusak, P., J. Plomerova, and V. Babuska, A model of the lithosphere thickness in the region of the Carpathians, Studia Geophys. Geod., 33, 11-21, 1989.

Panto, Gy., and T. Poka, Hungarian National Report on IASPEI (1995-1998), Acta Geod. Geophys. Hung., 34, 349-365, 1999.

Planation Surfaces in Europe, Asia and Africa (in Russian), VINITI, Moscow, 1973.

Pogacsas, Gy., Seismic stratigraphic features of Neogene sediments in the Pannonian basin, Geophys. Trans., 30, 373-410, 1984a.

Pogacsas, Gy., Results of seismic stratigraphy in Hungary, Acta Geol. Hung., 27, 91-108, 1984b.

Pogacsas, Gy., Investigation of the hydrocarbon geological role of neotectonic deformations in Hungary by means of seismic, paleomagnetic and radiometric data, pp. 1-12 Geofizikai Kutato Vallalt, Budapest, 1987a.

Pogacsas, Gy., Int. Workshop on Computerized Basin Analysis with Special Emphasis on Hydrocarbon Exploration (Abstracts), pp. 1-13, Szeged, 1987b.

Pogacsas, Gy., A. Jambor, R. Mattick, et al., Correlation of seismo- and magnetostratigraphy: Chronostratigraphy and the evolutionary sequence of rock units in the Pannonian Basin, in Abstracts. Int. Workshop on Computerized Basin Analysis with Special Emphasis on Hydrocarbon Exploration, pp. 1-13, Szeged, 1987a.

Pogacsas, Gy., B. Szanyi, and J. Szulyovszky, Seismological studies of Mesozoic-Neogene Sediments in SE-Hungary for Oil and Gas, Acta Geol. Hung., 30, 177-196, 1987b.

Posgay, K., and K. Szentgyorgi, A litoszferat harantolo eltolasos toresrendeszer a Pannonmedence keleti reszen, Magyar Geofiz., 32, 1-15, 1991.

Posgay, K., I. Albu, G. Raner, and G. Varga, Characteristics of the reflection layers in the Earth's crust and upper mantle in Hungary, in Reflection Seismology: A Global Perspective, pp. 55-65, Am. Geophys. Un., Washington, 1986.

Poultidis, C., Petrologie und Geochemie basaltischer Gesteine des steirischen Vulkanbogens in Steiermark und im Burgenland, Dissertation zur Erlangung des Doktorgrades an der Naturwissenschaftlichen Fakultat der Universitat Wien, Wien, 1981. Radler, B., J. Rumpler, I. Varga, and B. Vandler, Some of the results gained with seismic prospecting in deep sedimentary basins of Hungary, Proc. XI Congress of the CarpathianBalkan Geological Association, pp. 141-146, Naukova Dumka, Kiev, 1980.

Redulescu, D., Volcanoes (in Russian), Nedra, Moscow, 1979.

Royden, L. and J. Sclater, The Neogene intra-Carpathian basins, Phil. Trans. R. Soc. Lond., A300, 373-381, 1981.

Royden, L., F. Horvath, and J. Rumpler, Evolution of the Pannonian basin system. 1, Tectonics, 2, 63-90, 1983a.

Royden, L., F. Horvath, A. Nagymarosy, and L. Stegena, Evolution of the Pannonian basin system. 2. Subsidence and thermal history, Tectonics, 2, 91-137, 1983b.

Scholz, C. H., M. Barazangi, and M. L. Sbar, Late Cenozoic evolution of the Great Basin, Western United States, as an ensialic interarc basin, Geol. Soc. Am. Bull., 82, 1979-2990, 1971.

Schultz, S. S., Tectonics of the Crust (in Russian), Nedra, Leningrad, 1979.

Sclater, J. G., L. Royden, F. Horvath, et al., The formation of the Intra-Carpathian basins as determined from subsidence data, Earth Planet. Sci. Lett., 51, 139-162, 1980.

Seismic Safety of the Paks Nuclear Power Plant, Akademia Klado, Budapest, 1997.

Smith, A. G., Alpine deformation and the oceanic areas of the Tethys, Mediterranean, and Atlantic, Geol. Soc. Am. Bull., 82, 2039-2070, 1971.

Southern Black Sea Volcanic Belt and Its Metallogeny (in Russian), Nauka, Moscow, 1985.

Sovchik, Ya. V., Tectonic regionalization and structural development of the Ukrainian Carpathians (in Russian), Geotektonika, (5), 47-60, 1984.

Stille, G., Selected Works (in Russian), Mir, Moscow, 1964.

Steckler, M. S., and A. D. Watts, Subsidence of the Atlantic type continental margin off New York, Earth Planet. Sci. Lett., 41, $1-13,1978$.

Structure of the Crust and Upper Mantle of Central and Eastern Europe (in Russian), Naukova Dumka, Kiev, 1978.

Structure of the Crust of Central and Eastern Europe from Data of Geophysical Studies (in Russian), Naukova Dumka, Kiev, 1980.

Sviridenko, V. G., New global tectonics in relation to the Carpathian-Pannonian-Dinarides region (in Russian), Geotektonika, (1), 94-105, 1978.

Szabo, Z., E. Kilenyi, and B. Bardocz, Bouguer anomaly-depth to basement relations in the southern part of the Danube-Tisza interfluve, Hungary Geophys. Trans., 30, 411-424, 1984.

Szabo, Cs., Sz. Harangi, and L. Csontos, Review of Neogene and Quaternary volcanism of the Carpathian-Pannonian region, Tectonophysics, 208, 243-256, 1992.

Szeky-Fux, V., Z. Pecskay, and K. Balogh, Radiometric chronology of the buried Miocene volcanics of the northern and central Transtibiscia, Bull. Hung. Geol. Soc., 117, 223-235, 1987.

Szederkenyi, T., Petrological and geochemical character of the Bar basalt, Baranya county, South Hungary, Acta Min.-Petrogr. Szeged., XXIV, 235-256, 1980.

Tectonics of the Alpine Region (in Russian), Mir, Moscow, 1965. Tectonics of Europe and Adjacent Regions (in Russian), Nauka, Moscow, 1978.

The Heat Field of Europe (in Russian), Mir, Moscow, 1982.

Tokarski, A. K., Dynamics of Outer Carpathian Tertiary orogenesis, Publ. Inst. Geophys. Pol. Acad. Sci., A-8(130), 129-142, 1980.

Tomljenovic, B., and L. Csontos, Neogene-Quaternary structures in the border zone between Alps, Dinarides and Pannonian Basin (Hrvatsko zagorje and Karlovac Basins, Croatia), Int. J. Earth Sci., 90, 560-578, 2001.

Toth, T., and F. Horvath, Evidence for the Quaternary tectonic activity in the Paks area, Hungary, Acta Geol. Hung., 42, 327346, 1999.

Toth, L., P. Monus, and T. Zsiros, Hungarian Earthquake Bul- 
letin, 1995-2000, Georisk, Budapest, 2001.

Tsys, P. N., Geomorphological features of neotectonics in the Soviet Carpathians, in Neotectonic Movements and Structures of the Alpine Geosyncline Belt of Southwestern Eurasia (in Russian), pp. 126-131, Elm, Baku, 1970.

Vadas, E., Geology of Hungary (in Russian), Mir, Moscow, 1964.

Vaptsarov, I. N., N. P. Kostenko, T. I. Krystev, and N. N. Dunav, Postorogenic relief-forming structures in Bulgaria, in Geological Evolution of the Western Black Sea Basin (in Russian), pp. 3440, Bulg. Acad. Sci., Sofia, 1990.

Varsanyi, I., J.-M. Matray, and L. O. Kovacs, Geochemistry of formation waters in the Pannonian Basin (southeast Hungary), Chem. Geol., 140, 89-106, 1997.

Varsanyi, I., J.-M. Matray, and L. O. Kovacs, Hydrogeochemistry in two adjacent areas in the Pannonian Basin (southeast Hungary), Chem. Geol., 156, 25-39, 1999.
Vidrich, R., M. Rivicic, and P. Suhadolc, Seismogeological effects on rocks during the 12 April 1998 upper Soca Territory earthquake (NW Slovenia), Tectonophysics, 330, 153-175, 2001.

Weber, Z. Imaging $P_{\mathrm{n}}$ velocities beneath the Pannonian basin, Phys. Earth Planet. Inter., 129, 283-300, 2002.

Zsiros, T., An estimation of seismic hazard in Hungary, Gerlands Beitr. Geophys., 94, 111-122, 1985.

Zsiros, T., and P. Mones, Seismic activity in Hungary, Acta Geod. Geophys. Mont. Hung., 21, 209-214, 1986.

Zuchiewicz, W., Rates of neotectonic uplift: The Polish Carpathian example, Bull. INQUA, (13), 21-26, 1990.

(Received 11 September 2002) 